\title{
Transposition
}

Musique et Sciences Sociales

$4 \mid 2014$

Musique et conflits armés après 1945

\section{Mourning at the Piano: Marguerite Long, Maurice Ravel, and the Performance of Grief in Interwar France}

Faire son deuil au piano: Marguerite Long, Maurice Ravel et l'expression du deuil dans la France de l'entre-deux-guerres

\section{Jillian Rogers}

\section{OpenEdition}

Journals

\section{Electronic version}

URL: http://journals.openedition.org/transposition/739

DOI: $10.4000 /$ transposition.739

ISSN: $2110-6134$

Publisher

CRAL - Centre de recherche sur les arts et le langage

\section{Electronic reference}

Jillian Rogers, « Mourning at the Piano: Marquerite Long, Maurice Ravel, and the Performance of Grief in Interwar France », Transposition [Online], 4 | 2014, Online since 15 July 2014, connection on 13 November 2019. URL : http://journals.openedition.org/transposition/739 ; DOI : 10.4000/

transposition.739

This text was automatically generated on 13 November 2019.

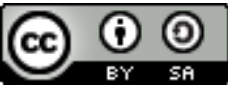

La revue Transposition est mise à disposition selon les termes de la Licence Creative Commons Attribution - Partage dans les Mêmes Conditions 4.0 International. 


\section{Mourning at the Piano: Marguerite Long, Maurice Ravel, and the Performance of Grief in Interwar France}

Faire son deuil au piano: Marguerite Long, Maurice Ravel et l'expression du deuil dans la France de l'entre-deux-guerres

Jillian Rogers

\section{Introduction}

1 In a letter to Alexis Roland-Manuel of October 1, 1914, Maurice Ravel writes, “I can't remain without news from my friends. From time to time I receive some frightful news, indirectly, which is then denied two days later. That's how I learned of Captain Marliave's death, and I don't dare write to his wife." Captain Marliave's wife was the esteemed French virtuoso pianist and pedagogue Marguerite Long, who was Ravel's close friend and preferred pianist in the years after the war. She premiered both his Le Tombeau de Couperin in 1919, and his Piano Concerto in G in 1932. In this same letter to RolandManuel, Ravel says that he has just begun working on the Tombeau, the neo-classical piano suite in which he dedicates each movement to a friend who died during the war. The suite's final movement, a rapid-fire, technically-demanding "Toccata," bears a dedication to the man whose death he mentions in this letter, Joseph de Marliave, who was killed on the front lines on August 24, 1914.

2 The premiere of Ravel's Tombeau took place four and a half years later on April 11, 1919, at a Société Musicale Indépendante concert in the Salle Gaveau. Considering the suite's dedications, how long it took the Tombeau to receive its first performance, and the fact that this was Ravel's first public appearance since finishing his wartime military service, it was surely an emotionally-charged evening for many in the hall that night, including the composer. Present on the concert program, as well as in the audience, was a virtual 
"who's who" of Ravel's Parisian social circle, a large number of whom had served in the war or lost someone close to them during the war's tenure. Ravel's good friend, the violinist Hélène Jourdan-Morhange, performed in Roland-Manuel's Trio, while the soprano Jane Bathori-also a close friend and one of Ravel's favorite singers-sang several songs by Gabriel Grovlez. Florent Schmitt's Quintette was also on the program, and Gustave Samazeuilh, Raoul Brunel, and Jean Marnold were in the audience. ${ }^{2}$ Considering their involvement with the Société Musicale Indépendante at the time, Gabriel Fauré, Louis Aubert, André Caplet, Jean Huré, Charles Koechlin, Jean Roger-Ducasse, and Nadia Boulanger were likely in attendance as well. ${ }^{3}$ We might imagine that Mme Fernand Dreyfus-Roland-Manuel's mother and Ravel's marraine de guerre-was present, especially since Ravel composed much of the suite while staying at her home in Lyon-la-Forêt during the summer and fall of 1917, a sad summer for Ravel since he was grieving his mother's death, which had occurred earlier that year. ${ }^{4}$ Moreover, Mme Dreyfus's stepson, Jean, was the dedicatee of the Tombeau's fifth movement. The family members of the other people to whom Ravel dedicated the Tombeau's movements were also likely in the Salle Gaveau that April evening, since Ravel was in most cases closer friends with the people who survived the dedicatees than the soldiers themselves. This was the case, for instance, with Jacques Durand, Ravel's publisher and the cousin of Jacques Charlot, to whom Ravel dedicated the Tombeau's "Prélude," as well as with Louise Crémieux, the Parisian socialite who had helped bring L'Heure espagnole to the Opéra-Comique in 1911, and whose son, Jean Cruppi, was the dedicatee of the suite's "Fugue." And, of course, there was Marguerite Long at the piano.

3 By the time of Le Tombeau de Couperin's premiere in 1919, Long and Ravel had been friends for quite some time. They had known each other from at least 1910, when Ravel had asked Long to recommend two students to premiere his Ma Mère l'Oye. ${ }^{5}$ Before the war the two musicians frequently saw each other at musical and social events since they had a number of friends and musical acquaintances in common. Although there is no extant correspondence between Ravel and Long from before the war, Ravel addresses Long as "Chère amie" in a letter dated July 1918, which indicates that the two had been fairly close for some time. ${ }^{6}$ After the war, Ravel and Long frequently toured together, especially with Ravel's Piano Concerto in $G$, and also continued to share the same group of friends, which included Nadia Boulanger, Ida Rubinstein, Hélène Jourdan-Morhange, RolandManuel, Marguerite de Saint-Marceaux, Lucien Garban, Darius Milhaud, Germaine Tailleferre, Francis Poulenc, and numerous other musicians, performers, and socialites living in Paris in the late teens, 1920s, and 1930s.

Although Ravel had finished composing Le Tombeau de Couperin in November 1917, he waited for almost a year and a half-through several scheduling mishaps and a number of Long's ailments-so that she could give the piece's first performance. He even overlooked a number of other talented performers who could have given the premiere, including likely candidates Edouard Risler and Robert Casadesus. ${ }^{7}$ Hélène Jourdan-Morhange referred to Ravel as an "incomparable friend" and explained that once he had decided that a friend would premiere a piece, he remained unmoved by offers from even the greatest musical celebrities. ${ }^{8}$ While this may have accounted for Ravel's holding out for Long to give Tombeau's premiere, a letter Ravel wrote to Long on January 14, 1920 suggests another reason. Ravel writes, "I've begun to work again in a furious manner, as before. ... As before, but not quite: the last time was in St-Jean-de-Luz... No one better than you can understand my awful sadness." Although Ravel declines to say it directly, 
Long had to have known what he meant: the "before" to which Ravel referred was his last intensely productive period of compositional activity during the summer of 1914, which he had spent at St-Jean-de-Luz with his mother. For both Ravel and Long, the summer of 1914 was a happier time that was now tragically irrecoverable. It was a time before the dark years of the war when, amongst other tragedies, Long lost her husband and Ravel lost his mother. Clearly, Ravel expresses his sadness to his friend because he knows that she sympathizes with him.

In light of the close friendship that Ravel and Long shared in the years after the war, Ravel's Le Tombeau de Couperin, like his sympathetic letter to Long, can be understood as an expression of shared mourning. In the article that follows, I propose that Ravel's experience of mourning during and after World War I significantly informed this neoclassical piano suite..$^{10} \mathrm{I}$ argue that Ravel designed this piece as a musical gift for Long that not only acknowledged their shared experience of mourning, but also provided Long with a means of comfort and momentary relief from the pain of her grief. Specifically, I propose that Ravel composed his Tombeau in order to suit Marguerite Long's preferred style of piano playing-le jeu perlé-and her modality of practice, both of which I will demonstrate were particularly well-suited to helping her cope with the death of her husband. Moreover, analysis of the Tombeau within the context of other compositions written for Long in the years immediately following her husband's death, and other compositions Ravel wrote for friends in mourning during these years, suggests that the difficult-to-perform, highly repetitive, and rhythmically regular music that characterizes Ravel's Tombeau may have been understood by musicians in their circle to have therapeutic potential for at least some living with and attempting to manage the emotional turmoil brought about by grief.

\section{Ravel's Circle and Resistant Mourning in World War I- Era France}

6 During World War I new social rules for mournful display arose that made the open expression of personal grief within Ravel's circle more difficult than it had been previously. Social historian Philippe Ariès has argued that French attitudes towards death shifted at some point between the late-nineteenth and mid-twentieth centuries, observing that the "hysterical mourning" of the nineteenth century, in which mourning rituals were "unfurled with an uncustomary degree of ostentation," disappeared at some point in the twentieth century. ${ }^{11}$ "Too evident sorrow" came to be disdained, leaving "solitary and shameful mourning" as "the only recourse, like a sort of masturbation." Ariès observes that funeral ceremonies needed to "remain discreet and must avoid emotion" and that "the outward manifestations of mourning are repugned and disappearing." ${ }^{12}$ The shift that Ariès describes is evident in the funeral accounts, obituaries, and other reporting on musicians' deaths in Parisian daily newspapers and weekly or monthly music journals published between 1875 and 1925. An examination of these articles demonstrates that the ways in which mourning was depicted and expressed, as well as the ways in which people affectively responded to mourning, changed specifically during World War I. ${ }^{13}$ Prior to August of 1914, writers for the Parisian press sought to sympathetically recreate mournful affect in their readers by focusing on grief and mourners, and using first-person proclamations of grief. During the war, however, coverage of musicians' deaths became extraordinarily dry, emotionally 
detached, and formulaic. Impersonal lists of State officials present at funerals replaced detailed descriptions of mourners, and mourners began to articulate their sorrow in collective or national terms rather than in first-person narratives. ${ }^{14}$ This shift in the printed reactions to musicians' deaths both shaped and was shaped by nationalist wartime discourses-including trench newspapers and governmental speeches lauding the value of war widows-that suggested that the most grievable lives were those of soldiers who had died for France. ${ }^{15}$

7 In their correspondence, several people in Ravel's social circle articulate the guilt and shame that they felt about their expressions of grief during the war. Emma Debussy almost constantly apologizes to friends to whom she writes about her grief after the deaths of her husband in March 1918, and her 13-year old daughter Chouchou in July 1919. ${ }^{16}$ While mourning her husband, Emma Debussy writes to André Caplet and shares how much she is suffering, but clarifies that he should not believe that she has forgotten "all the heroes who have struggled for years." She apologizes for grieving so openly, and writes that she is "certain that [she's] annoying everyone with [her] sorrow." ${ }^{17}$ Less than a year and a half before her own death, Chouchou Debussy sheds light on her mother's concerns with emotional display, and demonstrates the extent to which she was painfully aware of the social moratorium on direct expressions of grief. In a letter to her halfbrother, she writes, "At the cemetery, Maman could not have controlled her feelings any better. As for myself, I could think of nothing but one thing: 'You must not cry because of Maman.' And so I gathered all my courage ... I did not shed one tear." Chouchou articulates the emphasis placed on keeping mourning to oneself in private as well, writing that "I wanted to burst into a torrent of tears, but I repressed them because of Maman. Alone throughout the night in the big bed with Maman, I was unable to sleep one minute. I developed a temperature, my dry eyes questioned the walls." ${ }^{18}$ Chouchou represses her grief because she knows that her mother cannot explicitly express hers, especially in this particular wartime context in which mourners' bodies were expected to appear as if nothing had happened. This is a phenomenology of grief felt as constraint, as an indescribable pain that wells up inside a mourner's body with no place for release. Such pain often only grows in attempts to conceal or repress it, as evidenced by Chouchou's statement that, several days after her father's death she feels her grief "all the more poignantly."

8 Another indication of the shame associated with grief during the war is the tendency of some people in Ravel's and Long's circle to judge harshly friends who grieve too openly or too much. Jean Roger-Ducasse offers an example of this in his criticism of Marguerite Long's grief. Although he had been close friends with her husband and was mourning his death as well, Roger-Ducasse chastises Long for not being able to contain her grief, referring to her as "obscenely egotistical," in part because she dwells on her negative emotions and shares them with others: "And then everything is awful, everyone is horrible, clergy, courts, army. This woman, she is the inverse of Pangloss." ${ }^{19}$ And on another occasion, he disdainfully points out her expression of sorrow as a cause for reproach: "She is more and more the same, with the same exaggerations, the same unhappy feelings." ${ }^{20}$ Similarly, Marguerite de Saint-Marceaux, a socialite, pianist, and a friend of Boulanger, Long, and Ravel, criticizes Ravel and his brother for their behavior at their mother's funeral, writing that, "both were in utter turmoil, incapable of reaction or self-control. A lamentable and distressing spectacle at this time when heroism displays itself as naturally as breathing." ${ }^{21}$ According to Saint-Marceaux, the Ravel brothers' 
reaction to their mother's death was not only unheroic, but also decidedly unnaturalespecially, she implies, for two soldiers. ${ }^{22}$ For at least some of Ravel's friends, then, the open expression of grief engendered the contempt, disdain, and shame of others.

In part, these new social rules for mourning led Ravel, Long, and many people in their social circle to adopt a style of mourning that has been termed "resistant" by psychoanalytic theorists, critical theorists, and cultural historians. ${ }^{23}$ Rather than striving to cut the libidinal ties that connected them to lost loved ones, these mourners enact a refusal to accept the loss and subsequent absence left by the death of a person close to them. Resistant mourning is sometimes an ethical or a political choice-as it is for Jacques Derrida and Patricia Rae, amongst others-that a mourner makes in order to avoid unjustly (mis)representing the person she has lost, or to use that loss as a means to enact social or political change. ${ }^{24}$ In other instances, the unspeakability of a loss, whether caused by guilt, shame, ambivalence, or resulting from social strictures that inhibit mourning, leads the mourner to subsume an object representation into their ego in a way that makes it difficult for the mourner to move past and accept fully the loss. ${ }^{25}$ According to post-Freudian theorists Nicolas Abraham and Maria Torok: "Inexpressible mourning erects a tomb inside the subject. Reconstituted from the memories of words, scenes, and affects, the objectal correlative of the loss is buried alive in the crypt as a full-fledged person, complete with its own topography." 26 The psychically internalized lost person then returns to "haunt" the mourner, often preventing him or her from fully accepting the loss.

The psychoanalyst Vamik Volkan explains that perennial mourners-his term for resistant mourners-usually betray the presence of the introject that haunts them through a number of common behaviors. In his decades-long study of hundreds of cases of mourning, he observes that perennial mourners' fixations on loss often produce a tendency to lose or misplace things. In addition, many perennial mourners use terms like "frozen" to describe their dreams and a general sense of being hopelessly static within their mourning process. Furthermore, perennial mourners typically focus on death, tombs, or cemeteries, obsessively read obituaries, and often talk about the person being mourned as if she or he is still present and watching over them. Particularly striking is perennial mourners' frequent development and subsequent use of what Volkan calls "linking objects." He argues that "through the creation of a linking object or phenomenon, the perennial mourner makes an 'adjustment' to the complication within the mourning process; the mourner makes the mourning process 'unending' so as not to face their conflicted relationship with the object representation of the deceased or lost thing." ${ }^{27}$ Volkan specifies that a linking object can be "a song, a hand gesture, or even a certain type of weather condition," but that no matter the object or objects chosen, the perennial mourner experiences these as "magical" objects that link them to the deceased person, serving as an "external bridge between the representations of the mourner and that of the lost person, just as the introject serves as an internal bridge." 28

11 Ravel and numerous people in his circle engaged in many of the behaviors Volkan describes. Ravel was particularly known, for instance, for misplacing things in the years after the war, as Marguerite Long recalls in her accounts of going on tour with Ravel in the 1920s and 1930s. ${ }^{29}$ But all the more striking are the archival materials of Marguerite Long and Nadia Boulanger, which demonstrate each woman's obsession with reading and collecting obituaries. Marguerite Long, for instance, wrote a fair number of obituariesincluding ones for Ravel, Ida Rubinstein, and the pianists Dinù Lipatti and Émile Sauer- 
but also collected and kept an extraordinarily large number of obituaries and funeral accounts. She collected as many as twenty press clippings after the sudden death in 1953 of her friend and business partner Jacques Thibaud. In addition, her archive contains various articles devoted to the deaths of Émile Sauer, Florent Schmitt, Anna de Noailles, Dinù Lipatti, and Paul Dukas. ${ }^{30}$ Roger-Ducasse confirms Long's preoccupation with scanning the papers for obituaries and other news items related to her husband's death in a 1915 letter he wrote to Lambinet, "Then Marg[uerite] shows us in Le Temps and Le Matin, the citation of our poor Jo...then Bruneau's article in Nouvelle Revue, then there was another in I don't know what." 31

Like Long, Nadia Boulanger was preoccupied with obituaries and funeral accounts. She kept quite a few obituaries that were printed after her sister Lili's death, as well as a scrapbook devoted entirely to articles on the death of her very close friend and fellow performer Raoul Pugno, with whom she was composing La Ville Morte when he died suddenly in January 1914. ${ }^{32}$ Boulanger's scrapbook dedicated to Pugno's death includes forty-seven pages of obituaries, funeral accounts, and other articles related to the pianist's death in six languages. Although she may have used a press clipping service for obtaining these excerpts, her handwriting appears underneath each one with the date and name of the newspaper in which the piece was found, demonstrating that she played an active role in constructing this memento. ${ }^{33}$ In addition, Hélène Jourdan-Morhange, one of Ravel's close friends and favorite performers, wrote quite a few obituaries, and also lovingly created two scrapbooks in memory of her friendship with Ravel: the first in relation to Ravel's Sonata for Violin and Violoncello and the other surrounding the composition of his Sonata for Violin and Piano. Both scrapbooks include a manuscript autograph of the score, and several letters from Ravel to Jourdan-Morhange in which he refers to the composition included in the scrapbook. ${ }^{34}$ These items demonstrate the strong need she felt to memorialize her friend after his death.

During and after the war, Ravel, Long, Emma Debussy, and Marguerite de Saint-Marceaux also demonstrate their resistant mourning through the frequent use of expressions in their correspondence, diaries, or memoirs indicating that they feel "stuck" in endless grief. Ravel's mother's death in January 1917 deeply affected him, leading many of his friends to assert that her death was not only a shocking blow at the time, but also a loss from which he never fully recovered. ${ }^{35}$ Much of Ravel's correspondence after his mother's death bears the markers of his deep and continuing grief over the loss of his mother, which Roger Nichols has argued was at least somewhat inflected by the guilt that Ravel must have felt after having left his mother alone-without the presence of either her husband, who had died in 1908, or of her sons, both of whom enlisted once the war broke out-in the last year of her life. ${ }^{36}$ Ravel writes to Manuel de Falla in September of 1919 to offer his condolences on the death of his mother, and tells him that he hasn't yet "pulled himself together," but that he hopes that his grief "will finally subside in the long run." Just three months later, Ravel writes to Ida Godebska that, "I'm thinking that it will soon be 3 years that she's been gone, and yet my despair increases daily." 38

Many of Ravel's closest friends after the war similarly allude to feeling trapped in infinite mourning. For instance, Marguerite Long refers to the three years after her husband's death as a time in which she was "buried" or "trapped" in her mourning. ${ }^{39}$ Similarly, Emma Debussy refers to her grief after the death of her husband as a "labyrinth of pain," and tells Marguerite Long after Chouchou's death that "the horrible nightmare" that she feels "so deeply in me," leaves her no longer knowing where she is ${ }^{40}$ Both phrases 
indicate her inability to move past or even see outside of her current state of mourning. Likewise, Marguerite de Saint-Marceaux repeatedly refers to endlessly mourning her husband, who died in April 1915. She writes almost six months after his death, for instance, that she senses that she is "in a moral distress" that she will "never be able to overcome." ${ }^{41}$

For this group of people, continuing to grieve-even if this experience was painful-was a way to keep their dead loved ones alive: it offered them a means to continue to connect with them, to not forget them, and, in not facing the loss as a loss, to avoid feeling the pain associated with that loss. There was even a paradoxical pleasure to be felt in this mournful existence, as Marguerite de Saint-Marceaux describes in her journal three months after her husband's death as "a painful melancholy but with pleasure." It is in this particular emotional state that she says she feels closer to her husband and "more in communication" with him. ${ }^{42}$ She also often uses her journal as a way of communicating with her husband, speaking to him on several occasions as if he were still alive, and asking him if he can see her pain and feel her tears. ${ }^{43}$ Emma Debussy, on the other hand, deeply desired the ability to maintain Debussy's and her daughter's constant presences after their deaths, but was also troubled by her failure to do so. She heartbreakingly writes to Marguerite Long after Chouchou's death in 1919: "I am still calling Chouchou... she no longer hears me!!" 44 She describes the way in which the reality of Debussy's absence disturbs her ability to keep him with her, telling André Caplet that she is afraid of going back to the home she had shared with Debussy (she and Chouchou had gone to St-Jean-de-Luz to avoid the bombardment of Paris happening at the time) because it will force her to face the reality of his death. She also adamantly articulates that the most important task in this period of mourning is to continue in this painful state, writing that, "the greatest tragedy, which could yet overtake me, would be to no longer feel this fervent search for His trace." ${ }^{45}$

Perhaps no one makes clearer the importance of continuing to suffer through the pain of one's losses than Maurice Maréchal, the accomplished cellist who premiered Ravel's Sonata for Violin and Violoncello with Jourdan-Morhange in 1921. He writes to Nadia Boulanger after her sister's death, and articulates his conception of resistant mourning with striking clarity. He sympathizes with Nadia, telling her that he "knows all that [she] must be going through" since he had experienced a loss similar to hers-the death of his fiancée Thérèse Quedrue in $1913 .{ }^{46}$ Then he writes,

The only true and long assuagement is to feel that the suffering doesn't pass. It would be too painful if it lasted only the strict duration of mourning prescribed; and then we accustom ourselves to it so well eventually; the true suffering would be to no longer suffer. The alleviation of grief must happen little by little; then, when the first bitterness and the first indignation has gone away, we find that sometimes we are able to relive happy memories, veritable minutes full of joy and happiness. They leave an impression that is so comforting, that not only has the being about whom we were just speaking, between close friends, been evoked, but that the reunion of the people who loved each other has indeed been realized anew. ${ }^{47}$

For Maréchal, resistant mourning offered a strategy for dealing with loss that allowed a mourner not only to remain faithful to the dead beloved, but also to gain a sense of comfort, even if only occasionally, in feeling that the lost person was actually with younot just evoked, but felt and experienced as if she were still living. In another letter, Maréchal responds to Nadia, "Indeed the only way of making dear departed beings live in oneself is to act and to think as if truly they acted and thought next to us-as actually 
truly living beings." ${ }^{18}$ Boulanger's and Maréchal's understanding of the relationship between the mourner and the mourned echoes descriptions of the introject-the psychic sign of resistant mourning-articulated by Volkan, Abraham and Torok, and Derrida. The idea that having the departed live "in oneself" and simultaneously "next to us," thus maintaining their own psychic boundaries that prevent them from being fully incorporated into the ego of the mourner, is precisely Abraham's and Torok's representation living in the crypt-"a complete person with his own topography"-or Volkan's introject-“an unassimilated object representation."49

18 The resistant mourning of Ravel, Long, and others in their circle is also evident in their use of specifically musical linking objects and practices to help them keep their cherished lost loved ones vividly present. Nadia Boulanger, for instance, held memorial concerts upon the anniversary of her sister's death until the end of her life. She frequently programmed her sister's music on the many concerts she organized and participated in, particularly on her tours of the United States. She even made organ arrangements of some of Lili's pieces so that she could play rather than conduct them on these tours. ${ }^{50}$ Gustave Samazeuilh, another member of this social circle, emphasizes the extent to which Nadia Boulanger's career changed almost entirely after the death of her sister, pointing out that, rather than continue to compose her own works, she chose to make known the works of her sister, and to devote the rest of her time to teaching. ${ }^{.1}$

Emma Debussy and Rosina and Laura Albéniz appear to have also used musical objects, performances, and practices as a way of linking them to lost loved ones. Rosina and Laura Albéniz-the wife and daughter of Isaac Albéniz, who had died in 1909-each write somewhat frantic letters to Marguerite Long asking for her assistance in getting Albéniz's Pepita edited and staged at the Opéra-Comique. At one point, Rosina asks Long to go see the publisher Eschig, arguing that only she could take care of this situation since Joseph de Marliave, who had assisted Albéniz with the libretto, and Albéniz were "two beings who were very dear to you." ${ }^{2}$ In this way, she uses the idea of Albéniz's Pepita as a musical link to their respective late husbands in order to convince Long to take action. Emma Debussy was similarly impassioned about arranging concerts of her late husband's music, but then, being immensely overwhelmed with emotion, was rarely able to stay after concerts to speak with friends and performers, which often resulted in apologetic letters later that evening or the next day. For instance, after the premiere of Debussy's Fantaisie in 1919, Emma writes to Long, asking her to forgive her for having left without seeing her. She says that she was "too upset to stay any longer," since, in hearing Long's performance, her "emotion was coupled by such a cruel grief," especially upon thinking about how much Debussy and Chouchou would have loved it. ${ }^{53}$

Ravel's linking objects after his mother's death can be understood as having taken two distinct shapes: the act of composition itself, and his preference for composing music for friends who were also in mourning. Ravel lived with his mother up until his departure for military service in the spring of 1916, and, as he told Ida Godebska in 1919, sitting down at the piano and settling back into intensive work reminded him of his mother's "dear silent presence enveloping me with her infinite tenderness," and made him feel her absence all the more strongly ${ }^{54}$ In September 1919, Ravel writes to Manuel de Falla that he is soon hoping to resume work, which he feels "would in any case be the best consolation, rather than forgetting, which I do not desire." ${ }^{55}$ Ravel's use of l'oubli-forgetting-is unclear here, and yet, considering the degree to which resistant mourning-mourning without forgetting-was prevalent in his circle, it makes sense to understand Ravel as expressing 
here his desire to not forget his mother. ${ }^{56}$ Composing music thus acts as a practice that links him to his mother, paradoxically providing him not only with comfort, but also with the pain of a loss that he does not want to forget.

The striking number of pieces that Ravel composed between 1914 and 1934 for friends who were also in mourning suggests that Ravel understood composing music as a way to cope with his own grief while providing others with musical means to cope with theirs. Compositions that Ravel wrote for friends in mourning include La Valse, dedicated to Misia Sert, whose estranged husband Alfred Edwards died in 1914; the Sonata for Violin and Violoncello, dedicated to Debussy, but intended to be performed by Maurice Maréchal and Hélène Jourdan-Morhange, both of whom were in mourning; the Sonata for Violin and Piano, also written for Jourdan-Morhange; the Chansons madécasses, which were intended to be performed by Jane Bathori, who had recently gone through a painful divorce from her husband; and of course his Piano Concerto in G and Le Tombeau de Couperin, both of which were composed for Marguerite Long. ${ }^{57}$ To be sure, so many people were touched by loss during the war that it might be argued that Ravel's dedications and performer choices would surely reflect this, regardless of whether he had these people's grief in mind as he wrote music for them. However, the extent to which Ravel appears to have been preoccupied with grief in the years after the war suggests that he was indeed invested in composing music for others in mourning. A number of Ravel's friends from the late teens and 1920s, for instance Erik Satie and Manuel Rosenthal, underline how much Ravel had changed after 1917. They often identify Ravel's mother's death as the source of this change..$^{58}$

Moreover, Ravel's choices to compose music for others in mourning appear as evidence of a larger shift in Ravel's postwar social network that accompanied the change in personality observed by Rosenthal and Satie. In her work on mourners, Phyllis R. Silverman has pointed out that people in mourning often seek each other out for support and comfort..$^{59}$ Similarly, Jay Winter has asserted the importance of kinship circles-nonfamilial social networks based on "fictive kinship"-that formed during World War I to facilitate consolation among mourners. ${ }^{60}$ Beginning in 1917 Ravel frequently chose to spend time with others in mourning. After his mother's death and his discharge from the military in early 1917, Ravel spent several months at the home of his marraine de guerre in Lyons-la-Forêt. At the time, Madame Fernand Dreyfus and her husband were coping with the death of their son Jean, who had been killed in action in the months prior. ${ }^{61}$ Although he never abandoned his friendships with the men he had come to know as "Les Apaches," or any of his other close friends from before the war, Ravel appears to have populated his social circle after 1917 with a number of performers who were also in mourning, including Marguerite Long and Hélène Jourdan-Morhange. ${ }^{62}$ Ravel's concern for the grief of his friends is also evident in the personal and touching condolences he took the time to write to Manuel de Falla, Hélène Kahn-Casella, Marie Gaudin, and Hélène JourdanMorhange when each was touched by loss in the late teens and early $1920 s .{ }^{63}$ Finally, Ravel demonstrates that the grief of his friends was at times integral to his compositional process in writing to Jourdan-Morhange in August of 1926 that " $[\mathrm{I} m]$ in the midst of [working on] the Sonata. [I] just had my inspiration refreshed in the waves of the ocean with Maurice Delage, who just lost his father." ${ }^{64}$ Ravel's concerns with his own grief, as well as his sympathy for others in mourning, suggest that he wrote music for mourning friends as an act of fictive kinship, and as a linking practice to help him to remember lost loved ones. 
Long's use of piano playing as a linking practice is suggested in the repertoire that she chose to perform in the years following her return to the stage in April 1917. This often consisted of music either beloved by her husband-which she likely played for him while he was still living-or that she was practicing in his presence before his death. ${ }^{65}$ Rehearsing these compositions in the home that they had shared together in order to prepare them for public performance would have offered her the opportunity to pay tribute to the memory of her husband, and also to recall what it felt like to practice and perform in his presence. The first piece that Long performed publicly after her husband's death was Vincent D'Indy's Symphonie sur un thème montagnard, one of several pieces Long had played in May 1914 in the last public concert she gave before Marliave was sent to the front. Moreover, in the spring of 1921, on the first full-length recital Long gave in Paris after her husband's passing, she chose to perform several pieces that would have served as very strong reminders of being in her husband's presence: Debussy's L'Isle Joyeuse, which she was working on in the summer of 1914, and which, she tells us in Au piano avec Claude Debussy, was the last piece Marliave heard her play before he left for the front, and Faure's Theme and Variations, and 6th and 7th Nocturnes, which were some of Marliave's favorites, as evidenced by his lengthy essay on Fauré's piano music for Nouvelles Revues. ${ }^{66}$ In his 1921 review of Long's recitals for Le Monde musical, Roger-Ducasse verifies that these concerts acted as mournful linking objects by noting that these performances were "a faithful tribute to a friend whose memory we honor." ${ }^{67}$

\section{Grieving at the Keyboard in Wartime France}

Many of Ravel's friends considered musical performance, especially at the keyboard, to be particularly helpful in coping with grief. This was the perspective of a number of musician-soldiers who express in Nadia and Lili Boulanger's Gazette des Classes du Conservatoire that time spent at the keyboard provided distraction, comfort, and a way of "becoming oneself again," at a time when they were attempting to cope with not only the loss of the life they had known before the war, but also unfathomable national and personal losses. Albert Bertelin, a Courrier musical critic who served in the war, writes that being able to place his fingers on the keyboard of a harmonium allowed him to "forget for a time the worries, the sadness, and the anguish of each day." ${ }^{68}$ Ernest Mangeret writes that "A few moments of leisure permitted me to become myself again...In these times, we found a piano in a half-demolished house, we went down into the basement (you can understand why!) and when the evening came, we came together, several friends, in order to make a little bit of music." ${ }^{69}$ After the death of her husband, Marguerite de SaintMarceaux frequently wrote that playing the piano was "the sole occupation that could make me endure life." Everything else, she tells us, "irritates her and makes her tired." André Messager, in a letter to Saint-Marceaux, confirms that he feels similarly about practicing the piano: "Music is the greatest consoler of broken hearts and those who love it and practice it as you do find in it the ability to heal the bloodiest of wounds." 71

When Long resumed practicing at home in January of 1915, Roger-Ducasse wrote to her in early February in order to express his happiness that she had begun practicing again:

Suzanne tells us that you started practicing the piano a little again. That makes me very happy, for nowhere will you find such a desire to live again; I say live again, for the months you have just been through have been for you as if you did not exist anymore, or rather, as if nothing in you existed anymore. There was nothing fair or 
right about this, which is why I am so thrilled to see you return to what may save you. ${ }^{72}$ functioned as a bodily prosthetic employed in the interest of emotional transformation, providing them with temporary emotional relief or comfort in the regular and repetitive movements of their fingers on the keys. Constantin Piron, in his 1949 method book for which Long wrote the preface, prefigures Tia DeNora's more recent assertion that music is a "prosthetic technology of the body" that has the potential to "lead actors to identify, work-up, and modulate emotional and motivational states." ${ }^{75} \mathrm{He}$ describes the piano as an instrument that extends the pianist's body and transforms her sensibility. ${ }^{76}$ Long, in her 1959 method book Le Piano, articulates the importance she finds in the sense of touch, writing that it is "a sense as rich and perhaps more essential than the senses of sight, hearing, or smell." "77 In addition, she demonstrates her belief that the kinesthetic movement of playing the piano affects a pianist's physical and mental state through quoting the surgeon Thierry de Martel, who wrote that, "it's not our mind that mobilizes our fingers, but rather our fingers and their nearly unconscious movements that give movement to our mind." 78

After 1914 Émile Jaques-Dalcroze argued that engaging in musical movement could engender emotional transformation in ways that would be beneficial for postwar society. Jaques-Dalcroze's writings and teachings achieved a fair amount of popularity in interwar Paris: his articles were frequently published in Parisian music journals, and his techniques were often showcased at the Conservatoire and the École Normale de Musique, both of which were institutions where Long, Nadia Boulanger, and Ravel taught or served on juries. ${ }^{79}$ In his eurythmic method, Jaques-Dalcroze posited that having students engage in rhythmically-organized kinesthetic activities would not only improve their musicality, but also their entire well-being and sense of self, which, he claimed, would help them to exteriorize their emotions in beneficial ways. In a 1919 article published in Le Monde musical Jaques-Dalcroze argues that his method is the key to healing neurasthenia, a nervous and physical disorder from which Ravel, amongst many others, was said to be suffering after the war..$^{80}$ Moreover, in an article published in Le Guide musical in 1918, he wrote that his method has as its ultimate goal improved concentration, physical economy, and the development of character, particularly achieved through "a regularization of nervous response for hypersensitive or disordered individuals." ${ }^{81}$ For Jaques-Dalcroze, "the joy of improving ourselves rhythmically and giving our entire bodies and souls to music," enabled his students to "exteriorize without constraint our sorrows and joys," which would, in turn, "provoke the blossoming of altruistic qualities necessary to a natural social life." ${ }^{82}$ 
Long was particularly attracted to a highly rhythmically regular and intensely kinesthetic style of piano-playing known as le jeu perlé, which Nicole Henriot-Schweitzer, a student of Long's, has described as requiring "fast finger-work very close to the keys so that a series of equally-sounded notes reminds us of uniformly shaped pearls on a string." ${ }^{83}$ The jeu perlé, characterized by its emphasis on notes of equal duration and quality, an excessively clear and pointed style of articulation achieved through highly regular finger motions, and a relatively sparse use of the pedal, not only required the consistent practice of etudes and exercises (particularly of the five-finger, scalar, and arpeggio variety), but was also somewhat modeled on the experience and clarity that came out of practicing these exercises. ${ }^{84}$ In all of her writings, and throughout her life, Long espoused the import of technical exercises to all manners and modes of performance. Several of Long's former students emphasize the importance of practice to Long, and the shape that practice took. Philippe Entremont, for instance, reports that "I got some very good practice techniques from her, things that I still do today-especially very slow practice, deep into the keys with high fingers." ${ }^{85}$ Henriot-Schweitzer, taking after Long, advocates "very, very slow practice, deep into the keys, without pedal, close and not brusque. I like to think of slow-motion films, with absolutely smooth and hypnotic movements-and I recommend this regardless of what the final tempo must be." 86

Long's "deep into the keys" approach, which hypnotically focuses attention on the pianist's fingers moving fluidly into, out of, and between the keys, might be understood as a meditative practice that allowed Long, and, I would suggest, Ravel and other French composers who had both experienced loss and who wrote music suited to the jeu perlé style, a way of rhythmically and kinesthetically bringing consistency and stability-a sort of concrete temporality-back to their bodies. ${ }^{87}$ It is exactly this sort of regular rhythmicity, corporeally enacted through a slow, repetitive and meditative walking or marching, that the French World War I soldier Maurice Genevoix names in his memoir, Ceux de 14, as both a source of his unending, resistant mourning-his inability to forget those who have died-and a means of consolation in his grief over his comrades' deaths: "Timmer the Deaf, Compain the Chatty, Perinet, Montigny, Chaffard; nothing but names. Still more, which leave me weary and panting: Durozier, Gerbeau, Richomme... I keep walking, rocked by a vague, regular, swinging. I don't find this hard; I don't try to escape; it seems to me that it's good like this." 88 In the section that follows, I analyze Ravel's Tombeau with an eye towards how the composer embedded this piece with musical elements that resonated with the jeu perlé style of pianistic performance. To this end, I focus particular attention on the corporeal gestures in which Ravel's suite invites its performers to engage. ${ }^{89}$

\section{Ravel's Tombeau as Grief Therapy}

31 Numerous commentators found Ravel's dedications for his Tombeau problematic. Due to the composition's title, the funeral urn that Ravel drew for the suite's title page, and Ravel's dedications to friends who died in the war, many of Ravel's contemporaries were "astonished that this homage to the dead should not have a funereal, or at least a morose quality." ${ }^{90}$ When Roger-Ducasse first heard Long perform the suite in 1918, he wrote that Ravel's dedications for the Tombeau would have been better suited to dancers or joyful girls, especially since the music was "devoid of any emotion, and which the memory of these soliders indeed calls for." ${ }^{\text {91 }}$ Long, however, defended Ravel's compositional choices, 
asserting that each of the Tombeau's movements need not be funereal or lamenting in order to be understood as sonic remembrances of the men to whom they are dedicated. ${ }^{92}$ Perhaps this was in part because she understood-through her own experience of playing them-that these pieces were still performances of mourning, even if not in the conventional sense that some of their contemporaries had in mind.

32 Specifically, Ravel's Tombeau allowed Long to engage in the particular type of practice she preferred after the death of her husband. By writing extremely difficult, highly repetitive, and kinesthetically-demanding music for her, Ravel gave Long a musical outlet not only to perform the sheer difficulty of grieving in wartime France, but also to engage in the jeu perlé style of piano playing that offered her a sense of comfort in the regular and hypnotic movements required of her fingers and hands. At least three of the movements of Le Tombeau de Couperin-the "Prelude," the "Toccata," and the "Fugue"-make demands on the pianist that border on the superhuman. In the suite's final movement, the "Toccata" dedicated to Long's husband that Long described as "especially dear to her," a flurry of constant staccato sixteenth notes crowds every bar save three: the final two bars of the movement, as well as one bar towards the end of the piece in which Ravel offers the performer a short moment of solace in a thirty-second-note rest marked with a fermata. ${ }^{93}$ The composer asks the pianist to play vif-around 144 beats per minute-for all but fourteen measures of the piece, which are marked, somewhat ironically, Un peu moins vif. While sometimes Ravel has both of the pianist's hands working together to maintain the perpetuity of the sixteenth notes, at other times, one hand plays sixteenth notes, while the other plays something else-sometimes more sixteenth notes, although at other times a countermelody or an accompanying figure (see Figure 1).

Figure 1: Maurice Ravel, Le Tombeau de Couperin (Paris, Durand, 1918); mm. 1- 56 of the "Toccata."
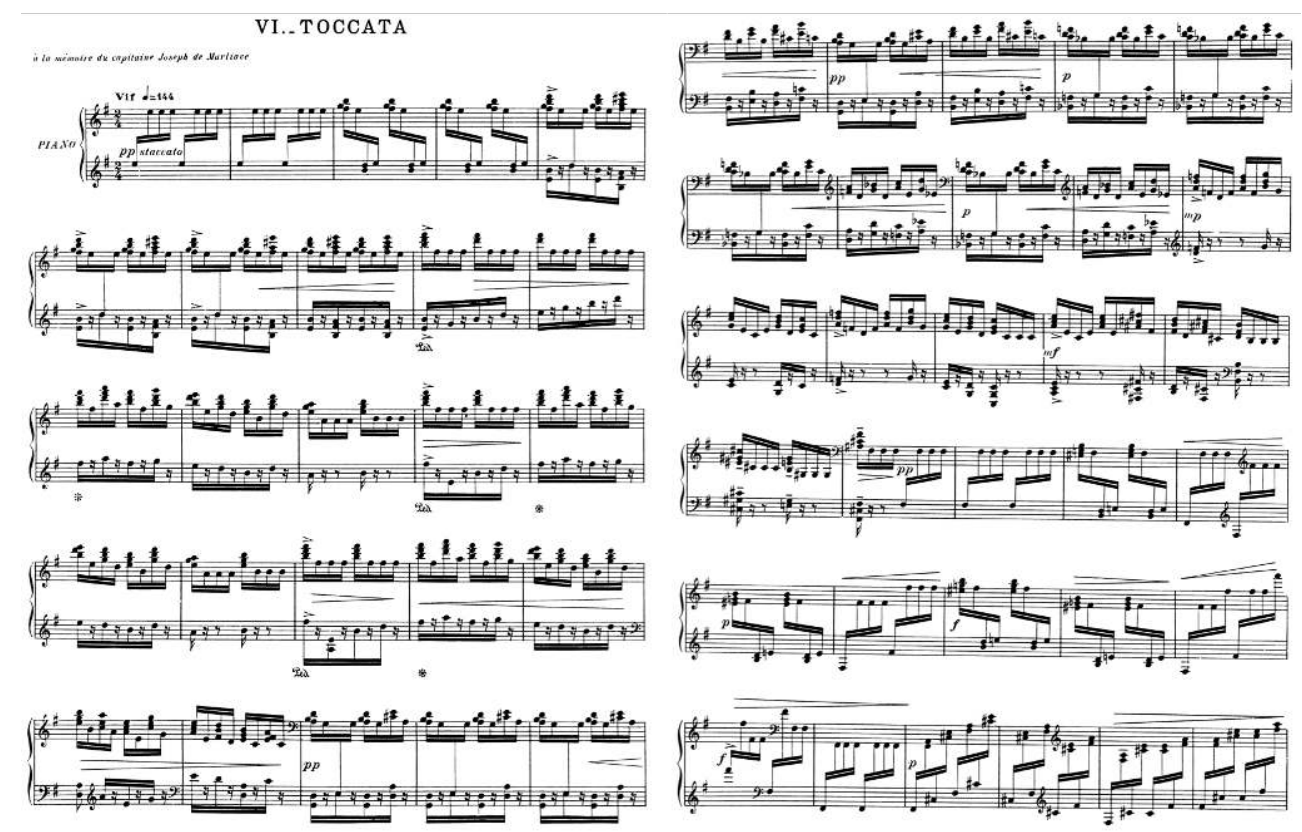

33 The same sort of perpetual and highly rhythmic hand and finger motion that Ravel demands of the performer in the "Toccata" is also required to play the suite's first movement. Ravel composed the Tombeau's "Prelude" so that the pianist is forced to play sixteenth-note sextuplets-in figurations that often resemble, draw on, and would likely benefit from technical exercises for the piano-at a breakneck pace (see Figure 2). With a 
metronome marking indicating a dotted-quarter note equals 92, the pianist plays just over 550 sixteenth notes per minute. Ravel has the performer play these uncomfortably fast sextuplets in one hand or the other throughout the entirety of the movement, with the exception of a sixteenth-note rest at the end of measure 85-hardly a moment of repose! Long was especially known for her accuracy in performing this movement, to the extent that Ravel often told his students not to play the movement as fast as Long for only she could play it so every note could be heard. ${ }^{94}$ Moreover, the Tombeau's second movement, an incredibly difficult "Fugue," requires an amazing degree of hand independence: the performer often plays duple meter in one hand and triple in the other, without the sort of regularity that might make this task somewhat easier. Interestingly, Long's solution for deficiencies in hand or finger independence laid in the return to technical exercises, in particular five-finger exercises. ${ }^{95}$

Figure 2: Maurice Ravel, Le Tombeau de Couperin (Paris, Durand, 1918); mm. 1-36 of the "Prélude."

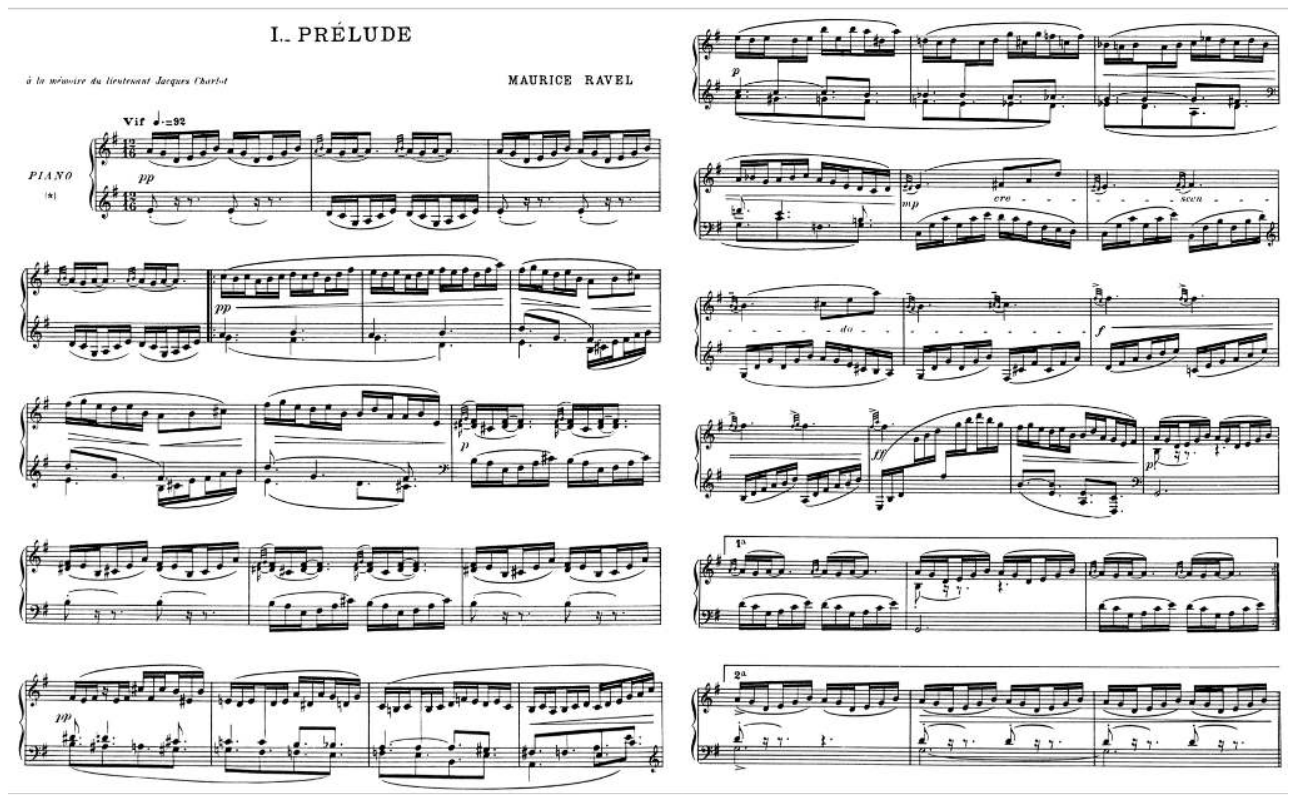

The corporeal challenges in the "Prelude," "Fugue," and "Toccata" of Ravel's Tombeau are exacerbated by the composer's only very rare indications that the performer should use the pedal or fluctuate in tempo in any way, which is a marked departure from Ravel's prewar piano repertoire. Indeed, compositions like Jeux d'eau (1902), "Une Barque sur l'Océan" (1906), and "Ondine" (1908), all feature extended passages of consistent sixteenth or thirty-second notes, often in the form of scales or arpeggios. However, in order to have them capture the sound, movement, and sensation of water, in these compositions Ravel asks his performers to adopt an aesthetic of fluidity and expressiveness through many slurred passages, heavy use of pedal, myriad meter and tempo changes, and instructions like d'un rythme très souple-très enveloppé de pédales, très fondu, and très expressif. The rubato-oriented aesthetic of these compositions is evident as well in the many instances of rallentando, ritardando, retenez, and accelerando that Ravel includes in these scores.

Similar passages of fast-moving sixteenth, thirty-second, or sixty-fourth notes appear in a handful of Ravel's early works not based on water themes, most notably in the Sonatine (1903-05) and "Scarbo" (1908). The first and third movements of the Sonatine are 
particularly laden with such passages; however, as in "Ondine," "Une Barque sur l'Océan," and Jeux d'eau, Ravel here employs a variety of tempi, as well as myriad markings encouraging pianistic flexibility, for instance très expressif, un peu retenu, and no less than nine ritardando/rallentando indications in the first movement alone. Moreover, in both of these movements Ravel gives his performers ample opportunities to shift out of these challenging passages and into somewhat easier, more melodically oriented material (see the shift at m. 13 in the first movement of the Sonatine in Figure 3 below). Ravel's "Scarbo" perhaps comes closest to approaching the demanding, perpetual motion oriented design of Le Tombeau's "Toccata." Both pieces, for instance, exhibit passages of repeated notes at nearly impossible tempi, and in "Scarbo," as in the "Toccata," Ravel demands that the pianist play many of these passages staccato and without pedal. However, because Ravel's goal in "Scarbo" is to sonically convey the erratic and unpredictable movements of this mischievous being, much of Ravel's writing in this piece is gestural (i.e. written so as to sound out the goblin's roguish scurrying, and perhaps the frantic confusion of the unlucky person who he haunts). "Scarbo" thus not only displays the frequent tempo changes and a significant reliance on the pedal that characterize Ravel's prewar rubato oriented style, but also offers the pianist many chances to "catch her breath," so to speak, in a plethora of pauses and eerie silences that make us wonder what the goblin's next move might be (see Figure 4).

Figure 3: Maurice Ravel, Sonatine (Paris, Durand, 1905); mm. 1-38 of the $1^{\text {st }}$ movement
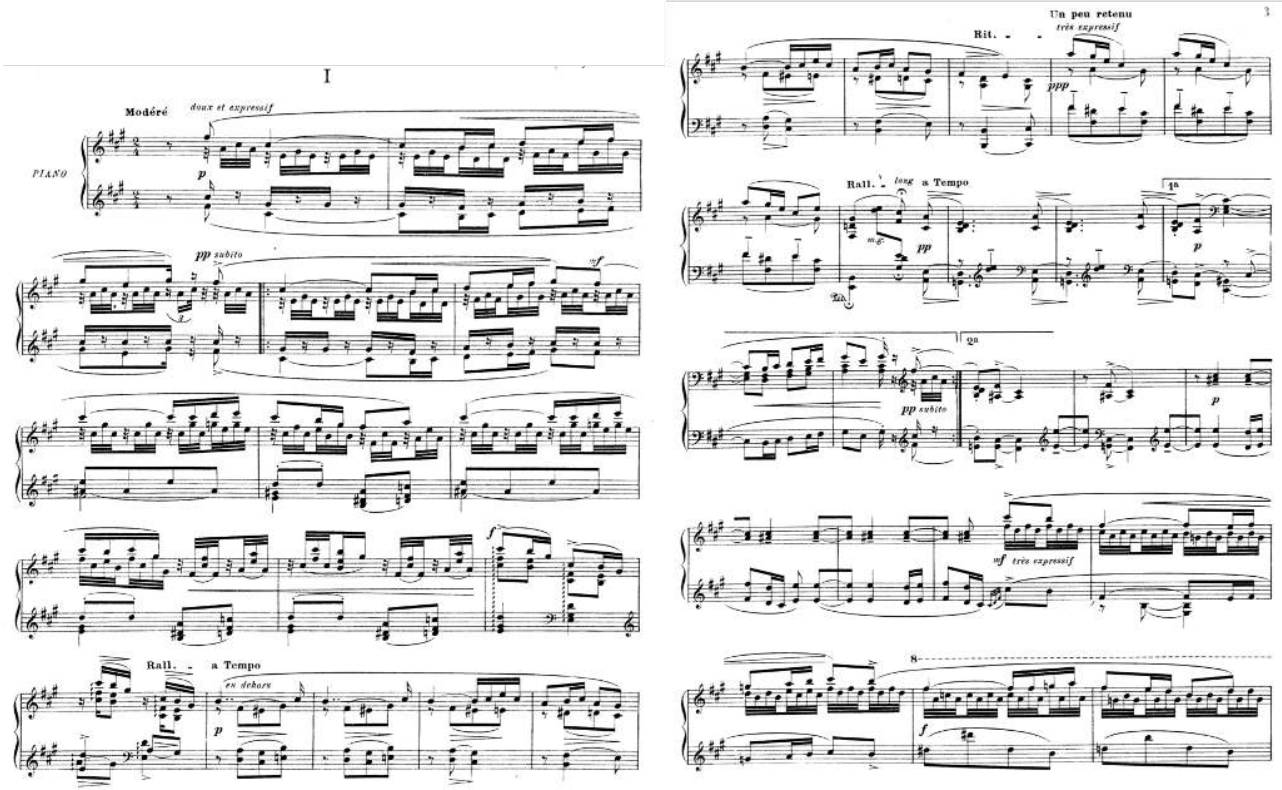
Figure 4a: Maurice Ravel, Gaspard de la Nuit (Paris, Durand, 1909); mm. 1-69 of "Scarbo."
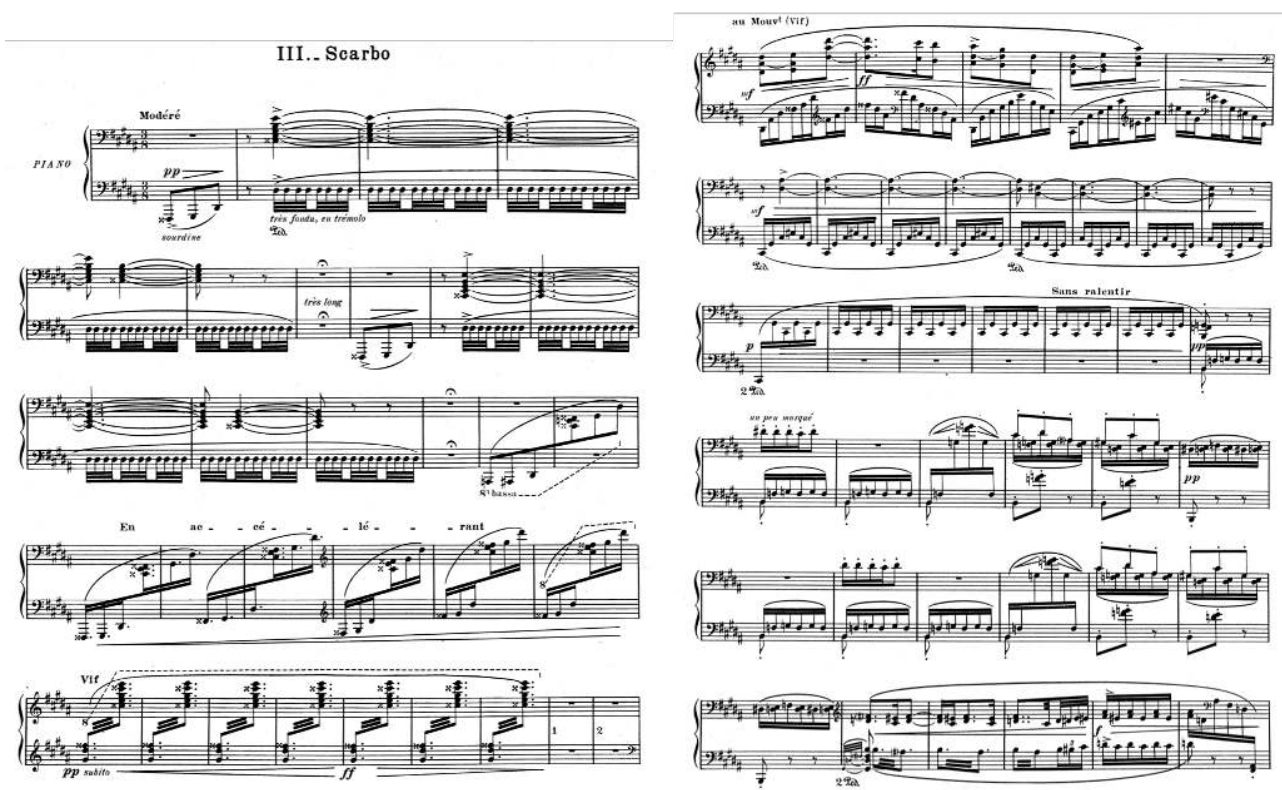

Figure 4b: Maurice Ravel, Gaspard de la Nuit (Paris, Durand, 1909); mm. 70-146 of "Scarbo."
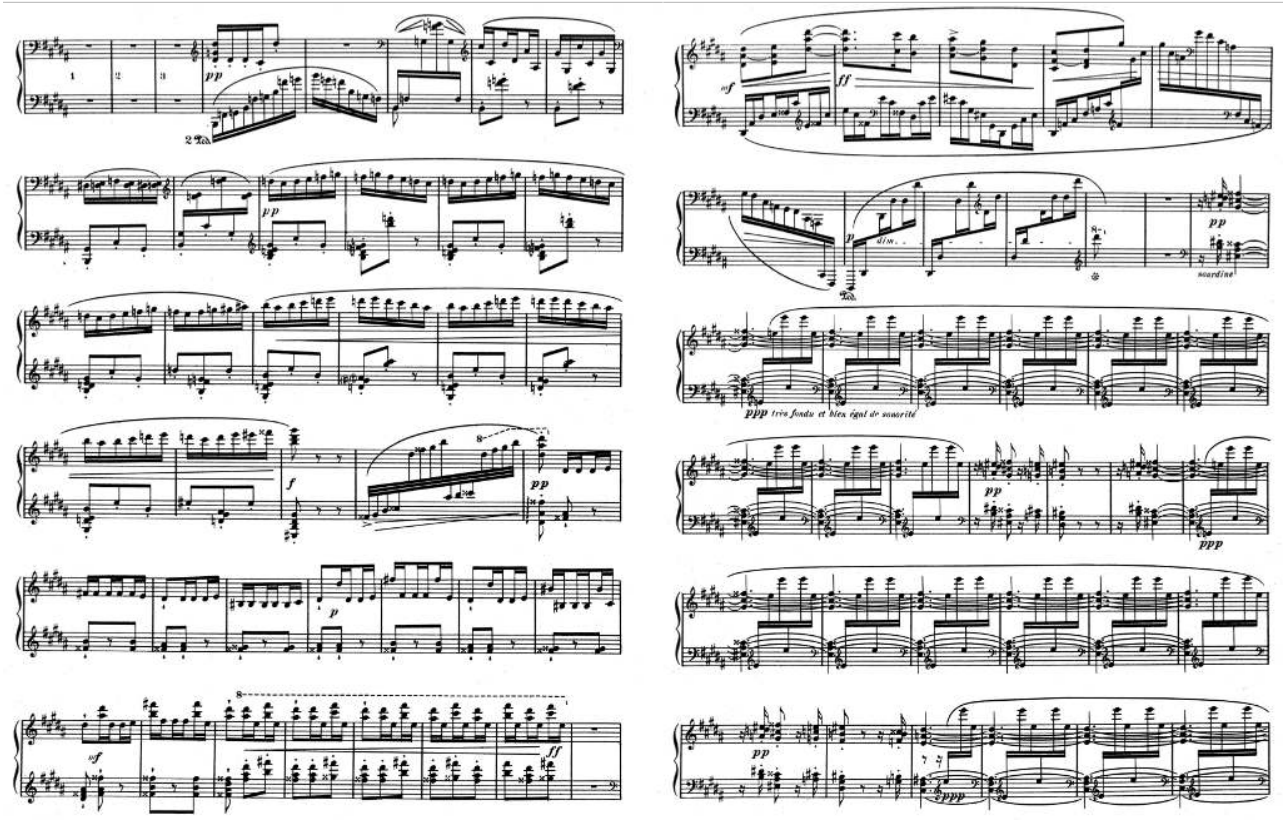

Unlike in his pre-war compositions, in Le Tombeau de Couperin Ravel demands extreme mechanicity from any performer of this piece: she must become like a human metronome ${ }^{96}$ Ravel replaces the rubatic with the robotic, forcing his pianist to play every note perfectly evenly, and almost never permitting her the opportunity to fluctuate in tempo, or to "hide" behind the pedal, which Long considered one of the greatest faults of amateur pianists. ${ }^{97}$ Ravel's "Prelude," for instance, is completely devoid of tempo changes or other instructions for expressive performance. In addition, Ravel prescribes using the pedal only in the final five measures of the movement, once the perpetual sixteenth notes have ceased their stirring. Similarly, the "Toccata" has only two tempo changes-the 
ironic un peu moins vif that occurs at m. 56 and its reversal to the original tempo fourteen measures later-and only three indications that the performer should indulge in using the pedal, all of which appear in the first twenty measures of the piece, lasting only one very quick measure in each case. In addition to what he included in the musical texts, Ravel's instructions to pianists affirm his desire for extreme precision. In one instance, he advised that the three interludes of the "Forlane" must be "metronomic." As for the "Toccata," Long tells us that Ravel's instructions were to "play 'all the notes' clearly and precisely in a movement which-apart from the tempo variation on page 26-must not slacken pace in the slightest degree right to the final octave." 98

A 1922 piano roll recording of the "Toccata" demonstrates the bodily strain of performing this piece. ${ }^{99}$ This corporeal struggle is sonically evident in the pianist's many failed attempts at rhythmic consistency. His hands limp through the piece, faltering particularly on passages with exposed repeated notes, of which there are many. It sounds a bit like a machine breaking down: notes follow one another jerkily just as a machine slows down and speeds up due to tiny bits of rust lodged in the grooves of its cogs. This recording demonstrates the performer's often futile efforts to maintain a steady tempo, to force his hands to participate in seemingly ceaseless attempts at kinesthetic, not to mention sonic, accuracy. These are strains of a performer's musculature, a push and pull felt in individual muscle fibers, as well as in his/her bones, specifically in the joints that are interstitial spaces of kinesthetic negotiation, and in his/her skin as it flexes in the movement of pressing down each key and jumping-sometimes nimbly but just as often awkwardly-from key to key. This feeling in and through the flesh might be understood as a physical transduction of the psychic and indeed physical pain experienced in intense grief.

Ravel's Tombeau, then, can be understood as particularly well suited to expressing and managing his and Long's shared resistant mourning. Many resistant mourners-and those in Ravel's circle were no exception-feel the paradoxical need to remind themselves of the loss they have experienced while simultaneously desiring to alleviate, even if ever so briefly, the pain of continuing to mourn. ${ }^{100}$ Thus while the difficulty of Ravel's Tombeau can be understood as a musical-performative analogue to the pain of grief, the gestures required to play Ravel's Tombeau also provided Long with a public opportunity to perform her grief in a way that would have circumvented the condemnation that was often the response to more personal expressions of grief in World War I-era France. Simultaneously, the affinity of Ravel's "Toccata" with the jeu perlé performance style would have provided Long with the opportunity to engage in a type of performance-as well as daily practice-that she personally enjoyed, thus offering her temporary distraction from her grief. In turn, the bodily re-entrainment effected through the repetitive, rhythmically regular, and hypnotic movements of Long's fingers and hands as she played Ravel's Tombeau would have provided her with a sense of bodily comfort and security within a psychic, physical, and social world rendered unstable and fractured by war and the grief that she was experiencing. ${ }^{101}$

\section{Beyond the Tombeau}

The corporeally demanding, rhythmically repetitive, and somewhat mechanical musical characteristics of Ravel's Tombeau appear in numerous compositions written in interwar France. The extent to which the resistant mourners in Ravel's circle sought to play music 
exhibiting these qualities suggests that music of this kind was considered to have therapeutic properties. ${ }^{102}$ Nadia Boulanger, for instance, chose to transcribe for organ and then perform Ravel's Tombeau on a 1925 American tour. For these same concerts, she transcribed her sister Lili's "Cortège," which, like Ravel's "Toccata" and "Prelude," features constant sixteenth-notes at a fairly quick tempo, and performed a number of compositions by Alexandre Guilmant, J.S. Bach, and Handel that display extended passages of perpetual-motion-style keyboard technique. ${ }^{103}$ While surely Boulanger was attempting to showcase French music as well as her own virtuosity on the organ, it is also possible that her tendency towards resistant mourning, as evidenced through her scrapbooks, correspondence, and the many concerts she organized in memory of her sister, led her to choose compositions that would allow her simultaneously to express and assuage her grief at the keyboard.

Furthermore, an examination of the repertoire that Long either chose to play, or that was specifically written for her after her husband's death - mostly by people who had themselves served in the war and suffered losses-suggests that music demanding the kind of égalité du mécanisme required by Ravel's Tombeau was specifically linked to coping with grief in World War I-era France. Roger-Ducasse's G-sharp minor Etude, which Long tells us was composed specifically as a way of persuading her to begin performing publicly again, demands an extraordinary degree of technical skill and employs a large amount of figural repetition. ${ }^{104}$ Subtitled "Étude pour notes repétées," this piece features extensive passages of consistent thirty-second notes that only let up three times throughout the piece, and never for more than two measures. After each of these midEtude moments of repose, the pianist must immediately return to her fast-paced perpetuum mobile. Although the performance directions indicate modéré, at a tempo of 76 beats per minute these thirty-second notes would go by at a quicker than comfortable pace. Roger-Ducasse composes lengthy passages where the performer plays the exact same fingering pattern over and over again, only shifting her hands up and down the keyboard according to pitch set. And, as in Ravel's Tombeau de Couperin, Roger-Ducasse denies the pianist any use of the pedal.

41 Two other pieces written during the war's tenure, and for which Long performed the premieres, feature similar musical qualities: Debussy's difficult and technically challenging Douze Études and Philippe Gaubert's Sonata for Flute and Piano. In the November 1917 concert that marked the Société Nationale's return to public performances, Long played three of Debussy's Douze Études-"Pour les "cinq doigts," "Pour les sonorités opposées," and "Pour les Arpèges composés"-which Debussy had written during the summer of 1915. Notably, "Pour les Arpèges composés" and "Pour les "cinq doigts"' exhibit lengthy passages of perpetual sixteenth-note sextuplets that are often juxtaposed with fast-moving duple-meter figures in the hand not playing the sextuplets, thus requiring incredible consistency and accuracy from the pianist, as well as a large amount of hand independence. The other etude Long chose to play, although not necessarily in the jeu perlé style, is still notably tied to mourning, since here Debussy heavily quoted his Berceuse héroïque, which he had composed less than a year earlier for the King Albert's Book, a collection of works paying tribute to the Belgian soldiers who died in their attempts to protect France from the German invasion in the summer of 1914. ${ }^{105}$ Similarly, Philippe Gaubert's Sonata for Flute and Piano, which Marguerite Long premiered with the composer at a Société Nationale concert on March 22, 1919, presents the 
pianistic performer with extended opportunities to play quickly-moving, highly technical, and repetitive passages of sixteenth notes.

Although these pieces in the jeu perlé style were written to match Long's performing preferences, they were also likely beneficial to others in Ravel's and Long's social circle, including the composers themselves. Philippe Gaubert, Roger-Ducasse, and Ravel were all soldiers in the war, knew people who had died during the war's tenure, and had significant losses to mourn. Gaubert, for instance, whose Sonata for Flute and Piano was completed in June 1917, writes a moving letter to Nadia Boulanger in April 1916 about having buried a friend of his who had been killed in the trenches on January $26^{\text {th }}$. He reports having lived through some tragic days since then, recounting that he had to tell their mutual friends of his death when he was on leave, and wondering how he has managed to remain "safe and sound" when so many of his friends had lost their lives. ${ }^{106}$ Roger-Ducasse, on the other hand, was mourning the death of Joseph de Marliave, and, as he wrote to Lambinet in April 1916, had become extraordinarily depressed while serving in the army. ${ }^{107}$ Similarly, when writing his Douze Études during the summer of 1915, Debussy was in the process of working through grief and depression. Like Roger-Ducasse, he had been close friends with Long's husband, and thus was mourning Marliave's death while also attempting to cope with what Long suggested was one of the deepest depressions of his life. ${ }^{108}$

Considering that each of these men-with the exception perhaps of Gaubert-was known to compose at the piano, ${ }^{109}$ their choices to compose some of their most technically challenging, etude-like, and repetitive works for piano during the emotionally difficult years of the war suggest that the compositions that they wrote for Long also offered each of them a means of musical solace. The remarks of Émile Vuillermoz about these composers' relationship with the piano support this idea. Vuillermoz, who was a friend of Debussy as well as a fellow classmate of Ravel, Gaubert, and Roger-Ducasse at the Paris Conservatoire, observed that for many composers, and especially for Ravel and Debussy, the piano acted as an "instrument-confessor" with which composers shared their secret feelings and desires. ${ }^{110} \mathrm{He}$ added, as well, that time spent at the keyboard rendered the piano's vibrating strings into extensions of the musician's nervous system. Thus it is not difficult to imagine that for Ravel, Debussy, Roger-Ducasse, and Gaubert, creating these challenging and yet somewhat hypnotic compositions gave them the opportunity to bring a sense of rhythmic stability and comfort back to their minds and bodies.

However, Ravel's Piano Concerto in G perhaps offers the best example, aside from the Tombeau, of how the relationship between pianistic performance and grief was understood amongst this group of friends. Although Ravel had initially wanted to compose a piano concerto to play himself, he decided instead to write a concerto specifically for Long. ${ }^{111}$ At the opening of the second movement, Ravel invites Long to perform her grief through a slow, melancholy waltz with a melody that, while incredibly beautiful, is heavy, languorous and dripping with pathos to an extent that little in Ravel's oeuvre can match (see Figure 5a). Long repeatedly voiced her anxiety over this particular passage, writing in 1945 that "this long, very long melody with its contained emotion," never ceased to worry her, both because of its expansiveness-it comprises nearly the first third of the movement-and the fact that Ravel forces her to play it completely solo, without the support of the orchestra. ${ }^{112}$ That this is Long's resistant mourning given musical voice is indicated by the melancholy nature of the theme, as well as its length, its inability to resolve, the awkward and uncomfortable fashion in which the melody fails to 
align entirely with the waltz rhythm, and the isolation and exposure the performer is asked to endure. In addition, when Ravel brings back this theme at the end of the movement, he gives this melody to the English horn, an instrument traditionally associated with mourning and lament. ${ }^{113}$

Figure 5a: Maurice Ravel, Piano Concerto in G (Paris, Durand, 1932); mm. 1-20.
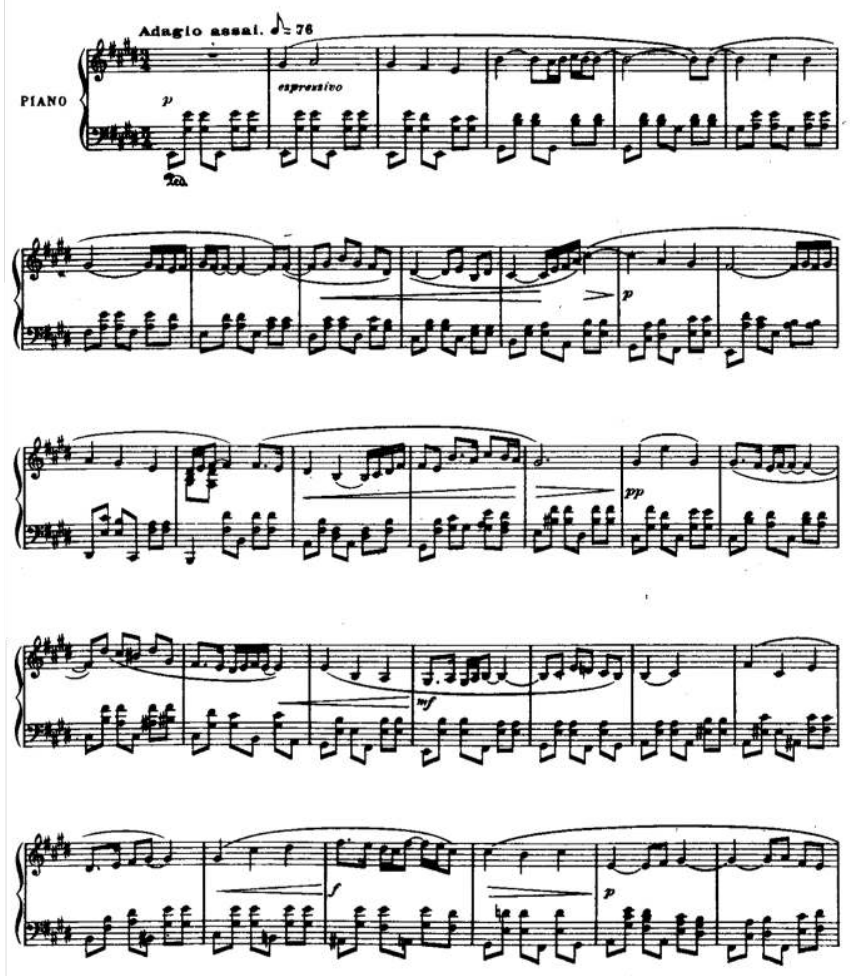

This moment of thematic return is not only unbelievably moving, but also communicates the important role that musical performance played in coping with grief for Ravel and Long. In yet another incredibly kind gesture of musical friendship, Ravel chooses this precise moment to give Long what he knows might help her most: the opportunity to hear her grief sympathetically voiced by someone else while her fingers move through measure after measure of technical-exercise-like and highly rhythmically regular passagework composed of steady thirty-second notes. This is her perfect jeu perlé (see Figure 5b). As in the "Toccata" of Le Tombeau de Couperin, here Ravel gives Long an extended moto perpetuo devoid of slurs, pedal, or expressive markings. ${ }^{114}$ Long's jeu perlé continues until the last six measures of the movement, when Ravel gives her the softly played trills he had once promised her. ${ }^{115}$ In these last six measures Ravel also provides an uplifting resolution to E-major that we have been anxiously awaiting for the entirety of the movement. By placing this moment of musical resolution right on the heels of Long's jeu perlé passagework, Ravel seems to articulate that through musical performance it is possible to achieve at least a moment of mental and emotional peace from one's grief. 
Figure 5b: Maurice Ravel, Piano Concerto in G (Paris, Durand, 1932), mm. 72-80. The English horn solo/recapitulation begins at $\mathrm{m}$. 74 .
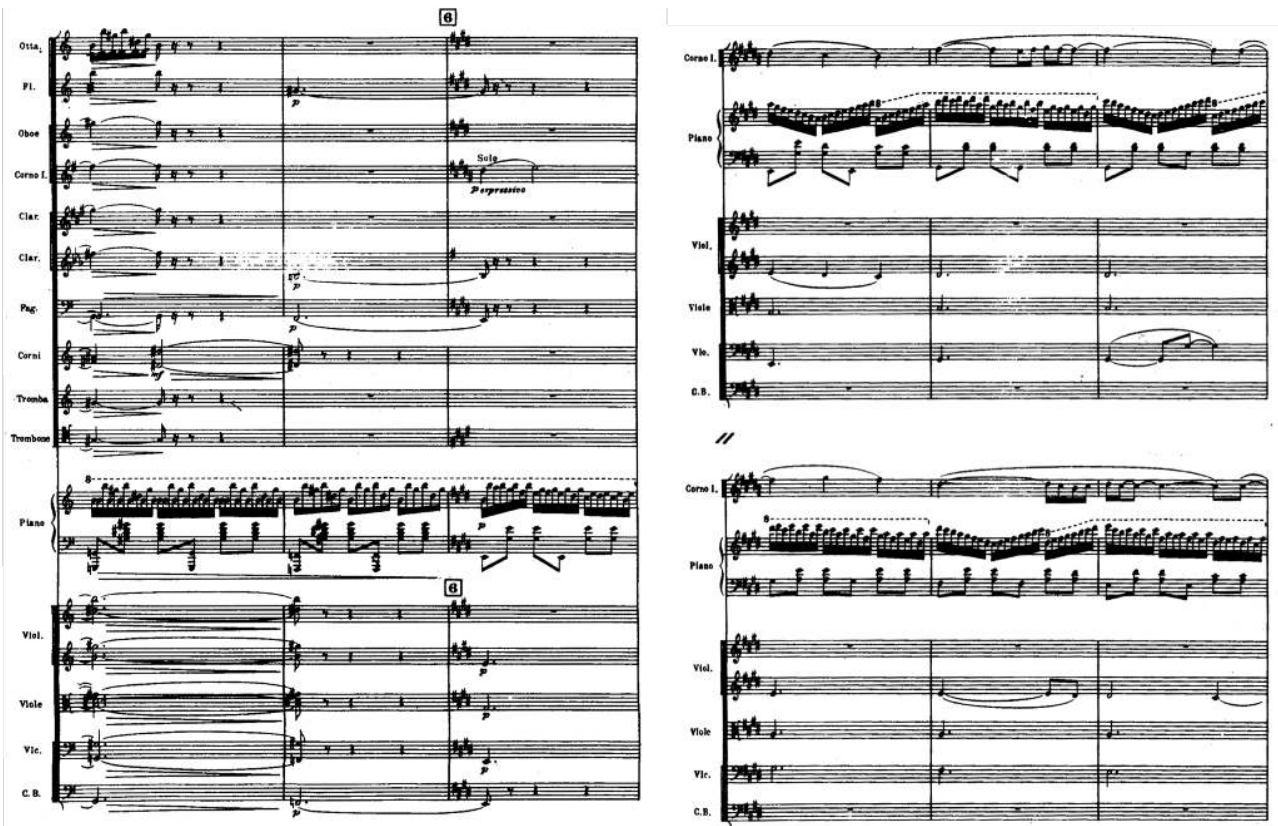

Ravel gave Long this Concerto just two days before her fifty-seventh birthday, on November 11, 1931. This was also the anniversary of the Armistice, a fact that had surely not escaped Ravel. In describing the first time she had the opportunity to play Ravel's Concerto in G, Long recounts, "I sat down to sight-read little by little these pattes de mouches, and when I arrived at this marvelous Andante, at the entry of the English horn, which repeats the phrase from the beginning of the movement with the thirty-second notes in the piano, I was so moved by it that I had tears in my eyes. They say that I play this concerto well. It is because it evokes for me so many poignant memories!" 116 Long's tenderly evoked memories were, we might imagine, of the happier years spent sharing a life with Joseph de Marliave before the war. However, it is likely that the concerto was also a touching reminder in sound and movement of her friendship with Ravel, their shared experience of resistant mourning, and the ways in which, for both of them, making music offered a way to express and cope with grief.

\section{NOTES}

1. RAVEL, Maurice, Letter to ROLAND-MANUEL, Alexis, 1 October 1914, in ORENSTEIN, Arbie (ed.), Lettres, écrits, et entretiens, Paris, Flammarion, 1989, p. 145; cited and translated in ORENSTEIN, Arbie (ed.), A Ravel Reader: Correspondence, Articles, Interviews, New York, Columbia University Press, 1990, p. 155-156: “Je ne peux plus rester sans nouvelles d'aucun ami...De temps en temps, on en reçoit d'affreuses, indirectement, qui sont démenties 2 jours après. C'est ainsi que j'ai appris la mort du capitaine Marliave, et que je n'ose rien écrire à sa femme." Unless otherwise 
noted, the translations that appear in this article are my own. This article was adapted from unpublished papers presented at the Symposium on the Art of Death and Dying at the University of Houston in October 2012, the annual meeting of the American Musicological Society in New Orleans in November 2012, and Esteban Buch's seminar, Musique et politique au XXe siècle at the École des Hautes Études en Sciences Sociales in Paris in February 2013. I am indebted to Professor Buch and the graduate students who attended his seminar, as well as to all of the respondents to previous versions of this paper for their invaluable feedback. I would also like to thank Nina Eidsheim for encouraging me to explore the relationship between grief and pianistic performance in her UCLA graduate seminar, Musicology in the Flesh, in the spring of 2010. In addition, I would like to thank Robert Pearson, Erin Jerome, Karen Turman, and Fanny Gribenski, as well as my fellow UCLA graduate students who participated in dissertation seminar in January 2013, for providing immensely helpful feedback on earlier versions of this paper. Finally, special thanks go to Tamara Levitz for her always thoughtful and invaluable comments on earlier versions of this article, as well as for her incredible and continuing support as my dissertation advisor. Funding for archival research for this article was generously provided through a Chateaubriand Fellowship and Phi Beta Kappa's Mary Isabel Sibley Fellowship.

2. Gustave Samazeuilh, Raoul Brunel, and Jean Marnold wrote reviews of this performance.

3. All of these people were serving on the Comité of the Société Musicale Indépendante in 1919, with the exception of Boulanger, who would be added to the Comité in Spring 1920.

4. Marraine de guerre translates literally as "war godmother"; in France during World War I many soldiers had a marraine de guerre who sent them care packages, and with whom they regularly corresponded. Ravel's mother died of natural causes on January 5, 1917.

5. LONG, Marguerite, At the Piano with Ravel, LAUMONIER, Pierre (ed.), SENIOR-ELLIS, Olive (trans.), London, J.M. Dent \& Sons Ltd., 1973, p. 89. The Médiathèque Musicale Mahler (MMM) holds a typed manuscript of an "Hommage à Marguerite Long, 4 Juin 1956" (most likely written by ESCHOLIER, Raymond), which explains that Ravel had been friends with Marliave before he knew Long, and that the couple was friends with Ravel from around 1908. MMM, Fonds Marguerite Long, Documents biographiques, Boîte 2.

6. RAVEL, Maurice, Letter to LONG, Marguerite, 2 July 1918, in CHALUPT, René and GÉRAR, Marcelle (eds.), Ravel au miroir de ses lettres, Paris, R. Laffont, 1956, p. 152-153.

7. In a letter of 23 February 1919, Ravel tells Long that Edouard Risler has been working on the suite, but that he hopes that she'll still be able to give the premiere; in CHALUPT, René and GÉRAR, Marcelle (eds.), op. cit., p. 164-165. Robert Casadesus, being a friend of Ravel's at this time, likely could have gained access to the score as well. He gave a concert in February or March 1918 on which he played Ravel's Sonatine (BRÉARD, R., "Concerts Divers. M. Robert Casadesus," Le Courrier musical, 15 March 1918, p. 138-139). Ravel at least appreciated Casadesus's interpretation of the suite since he asked Casadesus to accompany him to a 1922 piano roll recording session in which his Tombeau was to be recorded. It is still unclear as to whether the performer for that recording was Casadesus or Ravel.

8. JOURDAN-MORHANGE, Hélène, "Le grand musicien Maurice Ravel est mort," La République, 29 December 1937; JOURDAN-MORHANGE, Hélène, "Ravel à Montfort-l'Amaury," in Ravel par quelques-uns de ses familiers, Paris, Éditions du Tambourinaire, 1939, p. 167-168: "ami incomparable."

9. RAVEL, Maurice, Letter to LONG, Marguerite, 14 January 1920, in CHALUPT, René and GÉRAR, Marcelle (eds.), op. cit.,p. 168-169: “J'ai repris le travail, d'un manière acharnée, comme autrefois. ... Comme autrefois; pas tout à fait : la dernière fois c'était à St-Jean-de-Luz... Nulle mieux que vous ne peut comprendre ma tristesse affreuse."

10. Similarly, Deborah Mawer acknowledges the relationship between Ravel's "preoccupation with death" after 1917 and his musical output during these years in MAWER, Deborah, "Balanchine's La Valse: Meanings and Implications for Ravel Studies," The Opera Quarterly 22, No. 
1, 2007, p. 90-116. There are, of course, many other ways of understanding Ravel's Tombeau de Couperin, as per the beautiful readings of the suite performed by Carolyn Abbate and Glenn Watkins, amongst others. See ABBATE, Carolyn, "Outside Ravel's Tomb," Journal of the American Musicological Society 52, no. 3, October 1999, p. 465-530; and WATKINS, Glenn, Proof Through the Night: Music and the Great War, Berkeley, University of California Press, 2003. I hope that my reading of the piano suite will be understood as offering just one other perspective on Ravel's composition that has not been previously considered within the current scholarship on Ravel. For more on the myriad and complex ways in which Ravel's Tombeau, along with the remainder of his postwar oeuvre, can be understood as helping musicians to express and cope with grief, see my dissertation, "Grieving Through Music in Interwar France: Maurice Ravel and His Circle, 1914-1934," Ph.D diss., University of California at Los Angeles, 2014.

11. ARIÈS, Philippe, Essais sur l'histoire de la mort en Occident : du Moyen Âge à nos jours, Paris, Seuil, 1975, p. 57; translated in ARIÈS, Philippe, Western Attitudes Toward Death: From the Middle Ages to the Present, RANUM, Patricia M. (trans.), Baltimore, Johns Hopkins University Press, 1974, p. 67. "Le XIXe siècle est l'époque des deuils que le psychologue d'aujourd'hui appelle hystériques"; "le deuil s'est déployé avec ostentation au-delà des usages."

12. Ibid., p. 70; translated in ARIÈS, Philippe, Western Attitudes Toward Death, op. cit., p. 90: "Une peine trop visible n'inspire pas la pitié, mais une répugnance; c'est un signe de dérangement mental ou de mauvaise éducation; c'est morbide...le deuil solitaire et honteux est la seule ressource, comme une sorte de masturbation"; "Si quelques formalités sont maintenues, et si une cérémonie marque encore le départ, elles doivent rester discrètes et éviter tout prétexte à une quelconque émotion: c'est ainsi que les condoléances à la famille sont maintenant supprimées à la fin des services d'enterrement. Les manifestations apparentes du deuil sont condamnées et disparaissent. On ne porte plus de vêtements sombres, on n'adopte plus une apparence différente de celle de tous les autres jours."

13. See my dissertation, op. cit.

14. This is particularly evident in the obituaries written after the death on March 25, 1918 of Claude Debussy. Many journalists framed Debussy's death as a loss for the nation, rather than a personal loss. In contrast to obituaries and reporting on the deaths of Jules Massenet and Ambroise Thomas in the decades just prior to World War I, journalists writing about Debussy's death in 1918 use "we" rather than "I" to express their grief; this trend is apparent as well in the reporting on Camille Saint-Saëns's and Gabriel Fauré's deaths in 1921 and 1924, respectively. For more on this, see the my dissertation, op. cit.

15. See AUDOIN-ROUZEAU, Stéphane, Men at war, 1914-1918: national sentiment and trench journalism in France during the First World War, MCPHAIL, Helen (trans.), Providence, Berg, 1992; PETIT, Stéphanie, "Le Deuil des veuves de la grande guerre : un deuil spécifique ?" Guerres mondiales et conflits contemporains, No. 198, June 2000, p. 53-65; p. 64.

16. DEBUSSY, Emma, Letters to CAPLET, André, 14 April 1918, 20 June 1918, 3 or 4 August 1918, undated letter from late 1918 or early 1919, 15 September 1920, 20 September 1920; Bibliothèque Nationale de France (BnF), Département de la Musique (Mus.), Fonds André Caplet, Volume 1B, Nouvelles lettres autographes 269, Letters 170-173 and 182-183. DEBUSSY, Emma, Letters to LONG, Marguerite, undated, MMM, Fonds Marguerite Long, Correspondance.

17. DEBUSSY, Emma, Letter to CAPLET, André, 20 June 1918: BnF, Mus., Fonds André Caplet, Volume 1B, Nouvelles lettres autographes 269, Letter 171: "tous ces héros qui lutttent depuis des années"; "J'ai la certitude d'ennuyer tout le monde avec mon chagrin."

18. DEBUSSY, Claude-Emma, Letter to BARDAC, Raoul, 8 April 1918, in LESURE, François (ed.), Claude Debussy, Lettres, Paris, Hermann, 1980, p. 286-287; cited and translated in LOCKSPEISER, Edward (ed.) Claude Debussy, His Life and Mind, Cambridge, Cambridge University Press, 1978, p. 223-24: “Au cimetière, maman, naturellement, ne put se comporter mieux qu'elle le faisait et quant à moi, ne pensant plus à rien, sauf: "il ne faut pas pleurer à cause de maman"; "Un torrent 
de larmes voulait s'échapper de mes yeux mais je les refoulais immédiatement à cause de maman. Toute la nuit, seule dans le grand lit de maman, je ne pus dormir une minute. J'avais la fièvre et mes yeux secs interrogeaient les murs"; “je le sens plus poignant encore."

19. ROGER-DUCASSE, Jean, to LAMBINET, André, 19 March 1916; in DEPAULIS, Jacques (ed.), Lettres à son ami André Lambinet, Sprimont, Mardaga, 2001, p. 110-111: "obscènement égoïste"; "Et puis tout va mal, tout est mauvais, clergé, magistrature, armée. Cette femme, c'est Pangloss à l'envers." Ducasse's reference to Pangloss, the overly and bafflingly optimistic teacher in Voltaire's Candide, is actually a reference to Marguerite Long's late husband, Joseph de Marliave, who Ducasse often called by this nickname.

20. Ibid., p. 111-112: "Elle est de plus en plus la même, avec les mêmes exagérations, les mêmes sentiments malheureux."

21. SAINT-MARCEAUX, Marguerite de, in CHIMÈNES, Myriam (ed.), Journal: 1894-1927, Paris, Fayard, 2007, Entry of 7 January 1917, p. 926; cited and translated in NICHOLS, Roger, Ravel, New Haven, Yale University Press, 2011, p. 188. "Les deux frères sont désespérés, ils adoraient leur mère. On les portait presque. Ils ne pouvaient rester debout. Êtres déséquilibrés, incapables de réagir et de se dominer. Spectacle lamentable peu réconfortant par ce temps où l'héroïsme se dépense comme la respiration."

22. Maurice Maréchal also remarks upon the need to keep one's emotions to oneself in order to avoid mockery from other soldiers. MARECHAL, Maurice, in DUROSOIR, Luc (ed.), Deux musiciens dans la Grande guerre, Paris, Tallandier, 2005 [see especially the entries from 6 October 1914 (p. 240) and 13 April 1917 (p. 314)]. For more on the relationship between social rules regarding emotional display and World-War-I-era French cultures of heroic masculinity, see my dissertation, op. cit.

23. Many scholars have addressed this type of mourning, although not all of them use the term " resistant mourning" to describe it. Freud, for instance, referred to this as "melancholia" in FREUD, Sigmund, "Mourning and Melancholia [1917]," in STRACHEY, James (ed. and trans.), The Standard Edition of the Complete Psychological Works of Sigmund Freud, vol. 14, London, Hogarth Press, 1957, p. 238-258. For a more complete discussion of the history of the concept of resistant mourning than I have space to include here, see RAE, Patricia, "Introduction: Modernist Mourning," in RAE, Patricia (ed.), Modernism and Mourning, Lewisburg, PA, Bucknell University Press, 2007. Many of these theorists, particularly the psychoanalytic theorists and those working within trauma studies, emphasize that many different factors lead to someone becoming a resistant mourner, including the circumstances of the loved one's death, the relationship between the mourner and the deceased, and the amount of guilt that the mourner felt or continues to feel in relation to the person who has died. The ability to speak about the death in question, however, is a significant factor as well.

24. DERRIDA, Jacques, in BRAULT, Pascale-Anne and NAAS, Michael (eds.), The Work of Mourning, Chicago, University of Chicago Press, 2001; RAE, Patricia, op. cit.

25. In "Mourning and Melancholia" and other essays Freud uses the term "introjection" to describe the process by which the ego accepts painful losses. Nicolas Abraham and Maria Torok (see note 25), however, are primarily concerned with certain mourners' inability to subsume a loss into the ego in a way that acknowledges the painfulness of the loss; this failure of introjection is masked, they argue, by a « fantasy of incorporation» that engenders the psychic encryption of a lost love object. For more on this subject, see ABRAHAM, Nicolas and TOROK, Maria, "Introjection-Incorporation: Mourning or Melancholia," in LEBOVICI, Serge and WIDLÖCHER, Daniel (eds.), Psychoanalysis in France, New York, International Universities Press, 1980, p. 3-16.

26. ABRAHAM, Nicolas, and TOROK, Maria, in RAND, Nicholas T. (ed.), The Shell and the Kernel: Renewals of Psychoanalysis, Volume 1, Chicago, University of Chicago Press, 1994, p. 130. 
27. VOLKAN, Vamik D., "Not letting go: from individual perennial mourners to societies with entitlement ideologies," in FIORINI, Leticia Glocer, BOKANOWSKI, Thierry, and LEWKOWICZ, Sergio (eds.), On Freud's "Mourning and Melancholia," London, International Psychoanalytic Association, 2007, p. 102.

28. Ibid., p. 101-103.

29. LONG, Marguerite, "Souvenirs de M.L.: Albéniz, Debussy et Fauré," MMM, Fonds Marguerite Long, Documents biographiques, Boîte 2, Bio. 5.

30. MMM, Fonds Marguerite Long, Divers Matérials.

31. ROGER-DUCASSE, Jean, in DEPAULIS, Jacques (ed.), op. cit., 106: "Puis Marg. nous montre dans le Temps et le Matin, je crois, la citation du pauvre Jo...Puis l'article de Bruneau dans la Nouvelle Revue, puis d'un autre dans je ne sais quoi."

32. There were not very many obituaries for Nadia Boulanger to collect after the death of her sister on March 15, 1918 due to the Parisian press's need to focus on war-related events and deaths between August 1914 and November 1918; I discuss this at greater length in my dissertation, op. cit.

33. BOULANGER, Nadia, Raoul Pugne [sic]. Articles nécrologiques: recueil factice de coupures de presse, BnF, Mus., Vma 4043.

34. RAVEL, Maurice, Manuscript Autographs of the Sonata for Violin and Piano and the Sonata for Violin and Violoncello, The Pierpont Morgan Museum and Library (PMML), Robert Owen Lehman Collection, R252.S698.

35. See, for example, ROLAND-MANUEL, Alexis, Maurice Ravel, JOLLY, Cynthia (trans.), New York, Dover Publications, Inc., 1972, p. 80; and NICHOLS, Roger, op. cit.,p p. 187-189.

36. NICHOLS, Roger, op. cit., p. 187-88.

37. RAVEL, Maurice, Letter to DE FALLA, Manuel, 19 September 1919, in ORENSTEIN, Arbie (ed.), Lettres, écrits, et entretiens, op. cit., p. 176; translated in ORENSTEIN, Arbie, (ed.), A Ravel Reader, op. cit., p. 193: "Moi, je ne me suis pas encore repris"; "Peut-être cela finit-il par s'apaiser à la longue."

38. RAVEL, Maurice, Letter to GODEBSKA, Ida, 27 December 1919, in ORENSTEIN, Arbie (ed.), Lettres, écrits, et entretiens, op. cit., p. 178; translated in ORENSTEIN, Arbie (ed.), A Ravel Reader, op. cit., p. 195: "Je songe qu'il y aura bientôt 3 ans qu'elle est partie, que mon désespoir augmente de jour en jour."

39. LONG, Marguerite, Au piano avec Gabriel Fauré, Paris, R. Julliard, 1963, p. 72: “emmurée dans mon deuil."

40. DEBUSSY, Emma, Letter to CAPLET, André, postmarked 14 April 1918, BnF, Mus., Fonds André Caplet, Correspondance, Volume 1B, 170: "ce labyrinthe de douleur." DEBUSSY, Emma, Letter to LONG, Marguerite, undated, MMM, Fonds Marguerite Long, Correspondance: "Mais le cauchemar horrible dans lequel je suis est si profond en moi que je ne sais plus très bien où je suis."

41. SAINT-MARCEAUX, Marguerite de, in CHIMÈNES, Myriam (ed.), op. cit., Entry of 3 November 1915, p. 874: "J'y suis [sic] misérablement dans une détresse morale que je ne pourrai jamais surmonter."

42. Ibid., Entry of 1 July 1915, p. 862: "une mélancolie douloureuse mais avec plaisir"; "plus en communication.

43. Ibid., Entries of 1 Mai 1915-8 July 1915, p. 858-863.

44. DEBUSSY, Emma, Letter to LONG, Marguerite, undated, MMM, Fonds Marguerite Long, Correspondance: “Moi j'appelle toujours Chouchou...Elle ne m'entend plus!!"

45. DEBUSSY, Emma, Letter to CAPLET, André, postmarked 14 April 1918, BnF, Mus., Fonds André Caplet, Vol. 1B, 170: "Il me semble que le plus grand malheur qui pourrait encore m'accabler, serait de ne plus ressentir cette recherche passionnée de Sa trace."

46. DUROSOIR, Luc (ed.), op. cit., p. 223, fn. 3. 
47. MARÉCHAL, Maurice, Letter to BOULANGER, Nadia, 26 May 1918, Lettres de musiciens mobilisées ou de leur famille adressées au Comité franco-américain, BnF, Mus., Rés. Vm. Dos. 88 (6): “C'est pourquoi, je sais tout ce que vous pouvez souffrir. Le seul et vrai et long adoucissement est de sentir que la souffrance ne passe pas. Ce serait vraiment trop pénible qu'elle ne dure que la durée stricte d'un deuil; et puis - on s'habitue si bien à la longue; la vraie souffrance serait de ne plus souffrir. Il faut de reste que cela devienne peu à peu de la douceur; alors, à l'époque où la première amertume et la première révolte ont disparu, on trouve quelquefois, à revivre des souvenirs heureux, de véritables minutes de pleine joie et de bonheur. Elles laissent une impression si réconfortante, celle que l'être dont on vient de parler, entre intimes, n'a pas seulement été évoqué, mais que la réunion de tous ceux qui s'aimèrent a bien été réalisée à nouveau."

48. MARÉCHAL, Maurice, Letter to BOULANGER, Nadia, 15 May 1918, Lettres reçues par Nadia Boulanger sur la question de "Quelle musique après la guerre," BnF, Mus., Rés. Vm. Dos. 88 (4), 32: "Du reste, c'est bien le seul moyen de faire vivre en soi les êtres chers disparus, que d'agir et de penser comme si vraiment ils agissaient et pensaient à côté de nous - en êtres très réellement existants."

49. VOLKAN, Vamik D., art. cit., p. 98-99; ABRAHAM, Nicolas and TOROK, Maria, "IntrojectionIncorporation: Mourning or Melancholia," op. cit., p. 8.

50. See the concert programs for her US tour in January and February of 1925. BnF, Mus., Rés. Vm. Dos. 195.

51. SAMAZEUILH, Gustave, Musiciens de mon temps, chroniques et souvenirs, Paris, M. Daubin, 1947, p. 287. Jeanice Brooks further addresses how Lili's death affected Nadia Boulanger's career in The Musical Work of Nadia Boulanger: Performing Past and Future Between the Wars, Cambridge, Cambridge University Press, 2013.

52. ALBÉNIZ, Laura and ALBÉNIZ, Rosina, Letters to LONG, Marguerite, 7 January 1916 to 4 January 1923, MMM, Fonds Marguerite Long; ALBÉNIZ, Rosina, Letter to LONG, Marguerite, 4 January 1923, MMM, Fonds Marguerite Long, Correspondance: "deux êtres disparus qui vous furent très chers."

53. DEBUSSY, Emma, Letter to LONG, Marguerite, [December 1919], MMM, Fonds Marguerite Long, Correspondance: "J'étais trop bouleversée pour demeurer plus longtemps"; "mon émotion était doublée d'un si cruel chagrin."

54. RAVEL, Maurice, Letter to GODEBSKA, Ida, 27 December 1919, in ORENSTEIN, Arbie, Lettres, écrits, entretiens, op. cit., p. 178; translated in ORENSTEIN, Arbie (ed.), A Ravel Reader, op. cit., p. 195: "cette chère présence silencieuse m'enveloppant de sa tendresse infinie."

55. RAVEL, Maurice, Letter to FALLA, Manuel de, September 1919, in ORENSTEIN, Arbie, Lettres, écrits, entretiens, op. cit., p. 176; translated in ORENSTEIN, Arbie (ed.), A Ravel Reader, op. cit., p. 193: “...je n'ai pu encore me remettre au travail, et pourtant je sens que ce serait là, sinon l'oubli, que je ne désire pas, du moins le meilleur adoucissement."

56. NICHOLS, Roger, op. cit., p. 205. Nichols argues that it is possible to understand oubli as a reference to suicide, since oubli can also mean "oblivion." This seems unlikely, however, due to the fact that oubli, even if understood as "oblivion" still relates to memory in its contemporary etymology.

57. Hélène Jourdan-Morhange was also apparently mourning someone else in the $1920 \mathrm{~s}$, as evidenced by a condolence letter Ravel wrote to her on 23 October 1923, published in CHALUPT, René and GERAR, Marcelle (eds.), op. cit., p. 200-201. The editors articulate that this letter was in response to the death of Jourdan-Morhange's mother, but Colette's condolence letters to Jourdan-Morhange and her father dated 1 October 1934 suggest that Madame Morhange did not pass away until a decade after Ravel's letter. See Colette in VILLARET, Bernard (ed.), Lettres à Moune et au Toutounet: Hélène Jourdan-Morhange et Luc-Albert Moreau, 1929-1954, Paris, des Femmes, 1985, p. 100-101. 
58. SATIE, Erik, Letter to DREYFUS, Mme Fernand, 30 July 1917, in VOLTA, Ornella (ed.), Erik Satie: Correspondance Presque Complète, Paris, Fayard, 2000, p. 292-293; ROSENTHAL, Manuel, in conversation with Roger Nichols, in NICHOLS, Roger, op. cit., p. 190. Deborah Mawer has similarly noted what she terms Ravel's «preoccupation with death in MAWER, Deborah, art. cit., p. 90.

59. SILVERMAN, Phyllis K., Widow to Widow: How the Bereaved Help One Another, New York, BrunnerRoutledge, 2004, p. xiii.

60. WINTER, Jay, Sites of Memory, Sites of Mourning: The Great War in European Cultural History, Cambridge, Cambridge University Press, 1995, p. 30, 34, 46-48.

61. Jean Dreyfus is the dedicatee of the fifth movement-the "Menuet"-of Ravel's Le Tombeau de Couperin. It is not known precisely when he died, although it was sometime in late 1916 or early 1917.

62. For more on "Les Apaches" see PASLER, Jann, “A Sociology of the Apaches: 'Sacred Battalion' for Pelléas," in KELLY, Barbara, MURPHY, Kerry, and LESURE, François (eds.), Berlioz and Debussy: Sources, Contexts, and Legacies, Aldershot, England, Ashgate, 2007, p. 149-166. It seems particularly notable that Ravel chose to write so much of his postwar piano music for Marguerite Long, rather than for Ricardo Viñes, who had been his preferred pianist prior to the war.

63. See RAVEL, Maurice, Letter to FALLA, Manuel de, 19 September 1919, in ORENSTEIN, Arbie (ed.), A Ravel Reader, op. cit., p. 193; RAVEL, Maurice, Letter to KAHN-CASELLA, Hélène, 19 January 1919, in Ibid., p. 185 ; RAVEL, Maurice, Letter to GAUDIN, Marie, 6 January 1921, in DELAHAYE, Michele, "Lettres de Maurice Ravel à la famille Gaudin de Saint-Jean-de-Luz. Deuxième Partie: de 1919 à 1927," in Cahiers Maurice Ravel 10, 2007, p. 14-56; p. 17; RAVEL, Maurice, Letter to JOURDAN-MORHANGE, Hélène, 12 October 1923, in CHALUPT, René and GERAR, Marcelle (eds.), op. cit., p. 200-201.

64. RAVEL, Maurice, Letter to JOURDAN-MORHANGE, Hélène, 29 August 1926, in Manuscript Autograph of the Sonata for Violin and Piano, PMML, R252.S698: "Parme de Sonate. Suis venu rafraîchir l'inspiration dans les flots de l'Océan, auprès de Maurice Delage, qui vient de perdre son père."

65. In addition to the several pieces listed in this paragraph, throughout the 1920 s Long frequently performed a number of the compositions that she had been fond of performing in the winter and spring of 1914, including Fauré's Ballade, Beethoven's C Minor Piano Concerto, and Franck's Symphonic Variations. See DUNOYER, Cecilia, Marguerite Long: A Life in French Music, 1874-1966, Bloomington, Indiana University Press, 1993, p. 31-33, 35, 86. See also reviews of her performances of early 1914 found in a large scrapbook of press clippings in MMM, Carrière, Boîte 2. Similarly, Long added Fauré's Third Valse Caprice to her repertoire around the time that she met Joseph de Marliave in 1903, and the piece later appeared on the second of her 1921 recitals. See DUNOYER, Cecilia, op. cit., p. 21, 86.

66. LONG, Marguerite, Au piano avec Claude Debussy, Paris, Julliard, 1960, p. 21. Although several reviewers considered this Long's first solo recital in eleven years (see BERTELIN, Albert, " $\mathrm{M}^{\mathrm{me}}$ Marguerite Long," Le Courrier musical, 15 May 1921), it was actually her first recital in Paris in that time. She had performed in a solo recital to benefit prisoners of war at the Golf Hotel in Saint Jean-de-Luz in the summer of 1918. Her repertoire on this recital overlapped with that of her 1921 Paris recitals; in both, for instance, she performed Debussy's L'Isle Joyeuse. See DUNOYER, Cecilia, op. cit., p. 74.

67. ROGER-DUCASSE, Jean, "Les deux Concerts de Mme Marguerite Long," in Le Monde Musical 32, nos. 7 and 8, April 1921, p. 159: "Fidèle, ce faisant, au souvenir de l'Ami dont nous vénérons la mémoire."

68. BERTELIN, Albert, Gazette des Classes de Composition du Conservatoire BnF, Mus., Rés. Vm. Dos. 88 (1), № 1, [1915], p. 5-6: "Quelques heures claires viennent pourtant de temps à autre illuminer le morne enchaînement des heures sombres ce sont celles où, durant les Offices, je laisse errer un peu à l'aventure mes doigts sur le clavier d'un très modeste harmonium dans l'Eglise de Saint- 
Ouen-L'Aumône, j'oublie alors pour un temps, les soucis, les chagrins, les angoisses de chaque jour."

69. MANGERET, Ernest, in Ibid., № 5, [1916?], p. 22: “Quelques moments de loisir me permettent de redevenir un peu moi-même... Ces temps-ci, nous avons trouvé un piano dans une maison à moitié démolie, nous l'avons descendu dans une cave (vous comprenez pourquoi!) et le soir venu, nous nous réunissons, quelques amis pour faire un peu de musique."

70. SAINT-MARCEAUX, Marguerite de, in CHIMÈNES, Myriam (ed.), op. cit., p. 863-864: "Mon René adoré où es-tu? J'ai repris mon piano, j'ai pu jouer et même chanter... C'est la seule occupation qui pourra me faire supporter la vie" (p. 863); "Nous referons de la musique et c'est la seule chose qui me raccroche à la vie, tout le reste m'énerve et me fatigue" (p. 864).

71. MESSAGER, André, Letter to SAINT-MARCEAUX, Marguerite de, 8 August 1915, BnF, Arts du Spectacle, cited in SAINT-MARCEAUX, Marguerite de, in CHIMÈNES, Myriam (ed.), op. cit., p. 864, n. 1: "La musique est la plus grande consolatrice des cœurs meurtris et ceux qui l'aiment et la pratiquent comme vous y trouvent la guérison des blessures les plus saignantes."

72. ROGER-DUCASSE, Jean, in DEPAULIS, Jacques (ed.), Roger-Ducasse: lettres à Marguerite Long et à son mari, Joseph de Marliave, Paris, Observatoire Musical Français, 2007, p. 52: cited and translated in DUNOYER, Cecilia, op. cit., p. 68-69: "Suzanne nous dit que vous avez un peu recommencé à travailler votre piano : cela me réjouit car vous ne trouverez point ailleurs un aussi involontaire désir de revivre - je dis revivre, car les mois que vous venez de passer ont été pour vous comme si vous n'existiez pas ou plutôt comme si rien n'existait plus en vous. Or cela n'était ni la justice ni la raison et voilà pourquoi je me réjouis de vous voir revenir à ce qui peut vous sauver."

73. BRUNEAU, Alfred, Letter to LONG, Marguerite, January or February 1915, MMM, Fonds Marguerite Long, Correspondance: “Souhaitons donc qu'une paix glorieuse s'établisse chez nous durant 1915 et nous permette de reprendre notre travail qui, seul, adoucira nos peines et nous donnera la force de continuer notre route."

74. LONG, Marguerite, Au piano avec Gabriel Fauré, op. cit., p. 72: "Les jours passaient, sans m'apporter la résignation du sacrifice. Le renoncement me semblait être l'unique refuge. La musique seule m'était consolante. C'est elle qui m'a sauvée."

75. DENORA, Tia, Music in Everyday Life, Cambridge, Cambridge University Press, 2000, p. 107.

76. PIRON, Constantin, L'Art du Piano, preface LONG, Marguerite, Paris, Fayard, 1949, p. 39.

77. LONG, Marguerite, Le Piano de Marguerite Long, Paris, Salabert, 1959, p. III: "Le toucher est bien un sens aussi riche et peut-être plus essentiel que celui de la vue, de l'ouie, de l'odorat."

78. Ibid., p. III. Quoting MARTEL, Thierry de: "Je suis convaincu qu'à l'encontre de ce qui est généralement admis, ce n'est pas notre esprit qui mobilise nos doigts, mais nos doigts et leurs mouvements presque inconscients qui donnent le branle à notre esprit."

79. Jaques-Dalcroze lived in Paris between 1924 and 1926, and moved in the same general social circle as Long. BRUNET-LECOMTE, H., Jaques-Dalcroze, sa vie, son oeuvre, Geneva, Éditions Jeheber, 1950, p. 198; 207; 216-217.

80. JAQUES-DALCROZE, Émile, "La Rythmique dans l'Education Musicale," Le Monde Musical 30, no. 7, July 1919, p. 195.

81. JAQUES-DALCROZE, Émile, "La Rythmique, la Plastique animée et la Danse," in Le Guide musical , 1918, p. 652: "Tous ont pour but suprême un accroissement de la concentration psychique, une organisation claire de l'économie physique, une augmentation de la personnalité, grâce à une éducation progressive du système nerveux, un développement de la sensibilité chez les sujets insensibles ou peu sensibles et, au contraire, une régularisation des réactions nerveuses chez les individus hypersensibles et désordonnés."

82. Ibid., p. 659: "La joie d'évoluer rythmiquement et de donner tout son corps et toute son âme à la musique qui nous guide et nous inspire est une des plus grandes qui puissent exister... N'est-ce pas une jouissance d'ordre supérieur... que d'extérioriser sans contrainte nos douleurs et nos 
joies... cette jouissance... provoque l'épanouissement des qualités d'altruisme nécessaires à l'établissement d'une vie sociale naturelle."

83. TIMBRELL, Charles, French Pianism: An Historical Perspective, White Plains, NY, Pro/Am Music Resources, 1992, p. 72.

84. See LONG, Marguerite, La Petite Méthode de Piano, Paris, Salabert, 1963. In her method book for beginner pianists, Long consistently returns to the importance of exercises devoted to "l'agilité des doigts," all of which are perpetual motion style exercises designed to improve the smoothness of movement between fingers. I would like to thank Rémy Campos for the wealth of information he provided about le jeu perlé in his seminar at the Conservatoire National Supérieur de Musique et de Danse de Paris in Fall 2011.

85. TIMBRELL, Charles, op. cit., p. 74.

86. Ibid., p. 74-75.

87. The jeu perlé was one of numerous styles of piano playing taught and practiced in France at this time. Contemporaries of Long such as Alfred Cortot and Blanche Selva promoted pianistic performance styles that used far more of the wrist, arms, and upper body, as well as more pedal. Selva in particular advocated a style of playing largely centered around the "free fall" ("chute libre") of the hand and arm. For more on these styles of piano playing, see Timbrell's French Pianism, as well as CORTOT, Alfred, Principes rationnels de la technique pianistique, Paris, Senart, 1928 and SELVA, Blanche, L'Enseignement musical de la technique du piano, Paris, Rouart, Lerolle et Cie, 1916-1924. I do not wish to diminish the extent to which these performance styles may have been utilized as a means of coping with grief at the keyboard in World War I-era France. There were, I would argue, many different ways in which people used time at keyboard as a means of accomplishing emotional work, whether in France or elsewhere. Ruth Solie addresses this, for instance, in "'Girling' at the Parlor Piano," in Music in Other Words: Victorian Conversations, Berkeley, University of California Press, 2004. However, I focus on the jeu perlé style of playing throughout this article because of its particular importance to Long, and also because of the affinity between this style of piano performance and some of the kinds of music that Ravel and several of his contemporaries were composing for Long and others in mourning at this time.

88. GENEVOIX, Maurice, Ceux de 14, Paris, Seuil, 1984, p. 552; cited and translated in SHERMAN, Daniel, The Construction of Memory in Interwar France, Chicago, University of Chicago Press, 1999, p. 65. “Timmer le Sourd, Compain la Pipelette, Montigny, Chaffard; rien que des noms. D'autres encore, qui me lassent et m'essoufflent: Durozier, Gerbeau, Richomme... Je marche toujours, bercé d'un balancement vague, régulier. Je ne trouve pas que cela soit pénible ; je n'essaie pas d'y échapper ; il me semble que cela est bien ainsi."

89. Here, I take some of my methodological cues from Elisabeth Le Guin, whose groundbreaking work on Boccherini focuses on the corporeal experience of musical performance. See LE GUIN, Elisabeth, Boccherini's Body: An Essay in Carnal Musicology, Los Angeles, University of California Press, 2009.

90. NICHOLS, Roger, op. cit., p. 204.

91. ROGER-DUCASSE, Jean, Letter to LAMBINET, André, 6 May 1918, in Lettres à son ami André Lambinet, op. cit., p. 121: "Pas une mesure d'émotion, et cependant le souvenir de ces soldats l'exigeait."

92. LONG, Marguerite, At the Piano with Maurice Ravel, op. cit., p. 94.

93. Ibid., p. 97.

94. Ibid., p. 95.

95. LONG, Marguerite, Le Piano de Marguerite Long, op. cit., p. V.

96. As Deborah Mawer has demonstrated, Ravel's compositions both before and after the war exhibit his general penchant for mechancity. She notes as well, however, that there is something particularly "machinistic" about the aesthetic exhibited in Ravel's postwar compositions, citing Frontispice, the Sonata for Violin and Violincello, and the Sonata for Violin and Piano as examples 
(although she also cites the ticking clocks of the opening to L'Heure espagnole as a notable prewar example of Ravel's "machinistic" writing). MAWER, Deborah, "Musical objects and Machines," in MAWER, Deborah (ed.), The Cambridge Companion to Ravel, Cambridge, Cambridge University Press, 2000 , p. 64. As I discuss at greater length in my dissertation, op, cit.. numerous critics noticed that the fluid, sensually evocative, richly textured, and lush musical style that marked much of Ravel's music prior to the war, was replaced after 1917 by a more austere and detached musical style featuring less textural lushness, less flexibility, and more ostinato passages and motor rhythms, which they called dépouillée or "stripped down." See HIMONET, A., "Les Concerts. Concerts Durand." Le Courrier musical 29, no. 12, 15 Juin 1927, p. 358. Although Le Tombeau de Couperin is not often cited as an example of this style, it might be considered an important precursor.

97. LONG, Marguerite, Le Piano de Marguerite Long, op. cit., p. XV.

98. LONG, Marguerite, Au piano avec Maurice Ravel, Paris, Julliard, 1971, p. 146: "Voilà l'occasion, comme disait Ravel, de faire 'toutes les notes', de jouer clair et précis dans un mouvement qui, en dehors du changement de tempo de la page 26 , ne doit pas avoir la moindre défaillance jusqu'à l'ultime octave." Translated in LONG, Marguerite, At the Piano with Ravel, op. cit., p. 95, 97.

99. "Toccata: from Le Tombeau de Couperin," Ravel Plays Ravel, CD 14 201, Santa Monica, CA, Laserlight, 1995. As I mentioned in n. 7, whether this recording was made my Ravel or by Robert Casadesus remains contested.

100. I have already mentioned several instances of this paradox, but Nadia Boulanger, who often emphasized the paradoxical nature of resistant mourning practices, offers one additional and particularly clear example. On the title page of the first of three notebooks in which she recorded friends' death dates so that she could write to the survivors on the anniversaries of their deaths, Boulanger writes that "the dear memory [of Lili] that guides me, supports me...is to me at the same time so sweet and so cruel." BnF, Mus., Rés. Vmc. Ms. 129 (1): "Ce livre fut entre les mains de ma petite Lili - puisse-t-il ne voir passer que des jours dignes de son souvenir - année définitive peut-être et que je confie à la chère mémoire qui me guide, me soutient et m'est à la fois si douce et si cruelle." The contradictory character of resistant mourning has also been remarked upon by many post-Freudian psychoanalytic theorists and practitioners, as well as by a number of cultural critics and historians, critical theorists, and scholars working within trauma studies. For more bibliographic information and discussion of this subject, see RAE, Patricia, art. cit., p. 13-23. Moreover, contemporary artist Meg Rotzel acknowledges and offers a way to manage the inherent contradiction of resistant mourning. After her brother's death in 1997, she undertook a project in 2000 to create articles of clothing designed to "locat[e] the physical sensations of grief upon my body." Rotzel's "Mourning Hood" uses weights as a way of mimicking the physical sensation of grief, and paradoxically allowing a mourner to rhythmically re-entrain her body. ROTZEL, Meg, "Your Breath is Your Defense," c_m_l, < http://c-m-l.org/?q=node/199>, accessed 6 June 2010.

101. I would suggest that this is somewhat similar to how rhythmically regular music has been successfully employed in neonatal units to help infants achieve homeostasis and adjust to their new and often disorienting environments outside of the womb. See DENORA, op. cit., p. 75-89. These movements may have allowed her access to a sort of trance state in which she could feel herself temporarily freed from the pain of resistant mourning. For more on the relationship between music, trancing, and emotional comfort, see BECKER, Judith, Deep Listeners: Music, Emotion, and Trancing, Bloomington, IN, Indiana University Press, 2004, p. 147-149.

102. It could be argued that the resistant mourners in Ravel's circle operated within a specific "habitus of listening." See BECKER, Judith, op. cit., p. 69-86.

103. Programs for concerts given 9 January 1925 in the Grand Court of the Wanamaker Store in Philadelphia, PA, USA; 11 January 1925 at Carnegie Hall with the New York Symphony Orchestra, 
New York City, NY, USA; 15 January 1925 at the Wanamaker Auditorium in New York City, NY, USA; 21 January 1925 at The Cleveland Museum of Art; BnF, Mus., Rés. Vm. Dos. 195.

104. LONG, Marguerite, At the piano with Debussy, SENIOR-ELLIS, Olive (trans.), London, Dent, 1972, p. 11.

105. WHEELDON, Marianne, Debussy's Late Style, Bloomington, IN, Indiana University Press, p. 72-79.

106. GAUBERT, Philippe, Gazette des Classes du Conservatoire, op. cit., $\mathrm{N}^{\circ} 8$, [published in 1917, but comprised of letters from 1916], p. 17: "sain et sauf."

107. ROGER-DUCASSE, Jean, Letter to LAMBINET, André, 12 April 1916, in DEPAULIS, Jacques (ed.), Lettres à son ami André Lambinet, op. cit., p. 111.

108. LONG, Marguerite, At the Piano with Debussy, op. cit., p. 41.

109. It is likely that Gaubert composed at the piano as well; he was more well known, however, as a flutist and conductor.

110. VUILLERMOZ, Émile, "L'CEuvre de Maurice Ravel," in Maurice Ravel par quelques-uns de ses familiers, op. cit., p. 16-18.

111. As a letter from the French Ambassador in Berlin, André François-Ponchet, attests, Ravel was under a lot of pressure from the conductor Wilhelm Fürtwangler and the Berlin Philharmonic Orchestra to perform the concerto himself; however, the deterioration of Ravel's health and performing abilities performed him from being able to do so. See François-Ponchet's letter, dated 21 December 1931, in BnF Mus., Fonds Montpensier, cited in NICHOLS, Roger, op. cit., p. 322-323.

112. LONG, Marguerite, "La Musique de piano," in Maurice Ravel, Paris, Les Publications techniques et artistiques, 1945, p. 5-6: "cette longue, très longue mélodie avec son émotion contenue."

113. The English horn and oboe both have longstanding associations with elegiac expressions. One example of this is Tristan und Isolde's $3^{\text {rd }}$ act, in which the English horn symbolizes an exterior manifestation of Tristan's own sadness, and the tragic nature of the love story through the mournful alte Weise. See also Sandra M. Gilbert's discussion of the Greek elogoi, which was frequently accompanied by an "oboelike doublepipe called auos," in GILBERT, Sandra M., Death's Door: Modern Dying and the Ways We Grieve, New York, W.W. Norton \& Company, 2006, p. 120.

114. To the English horn player, however, Ravel gives the instruction expressivo.

115. According to Long, at some point in the late 1920s Ravel turned to her at a dinner party at Marguerite de Saint-Marceaux's home and announced, "I am composing a concerto for you. Do you mind if it ends pianissimo and with trills?" Long says that she happily agreed, but was surprised to find that the concerto did not, in fact, end with this gesture. The fact that the Andante movement ends piano and with trills is perhaps an indication that Ravel had the Andante movement in mind for Long from the very start. See LONG, Marguerite, Au piano avec Maurice Ravel, op. cit., p. 57 : "Un soir, à un dîner chez $\mathrm{M}^{\text {me }}$ de Saint-Marceaux, dont le salon était 'un bastion de l'intimité artistique,' selon le mot de Colette, Ravel me dit à brûle-pourpoint : 'je suis en train de composer un concerto pour vous. Est-ce que cela vous est égal qu'il finisse pianissimo et par des trilles? - Mais bien sûr!' lui répondis-je, trop heureuse de réaliser le rêve de tant de virtuoses." Translated in LONG, Marguerite, At the Piano with Ravel, op. cit., p. 39.

116. ESCHOLIER, Raymond [?], "Hommage à Marguerite Long, 4 Juin 1956," MMM, Fonds Marguerite Long, Documents biographiques, Boîte 2: "Je me mis à déchiffrer petit à petit ces pattes de mouches, nous dit Marguerite Long, et quand, j'arrivai dans ce merveilleux andante, à l'entrée du cor anglais qui répète la phrase du début avec les triples croches au piano, je fus si émue que j'en eus les larmes aux yeux. On prétend que je joue bien ce concerto. C'est peut-être parce qu'il évoque pour moi tant de poignants souvenirs !" 


\section{ABSTRACTS}

At the beginning of World War I, Maurice Ravel wrote to Roland-Manuel to tell him that he had begun composing the piano suite Le Tombeau de Couperin. In this same letter, Ravel relayed that he heard that Joseph de Marliave, the husband of pianist Marguerite Long, had been killed in combat. The fact that Ravel both dedicated Le Tombeau's final movement to Long's husband, and desired Long to premiere the work, suggests that the two news items in this letter are more connected than they at first appear to be. Ravel's contemporaries, in fact, recognized a connection between grief and musical performance, as Roger-Ducasse attests in writing to Long in 1915 that piano practice would give her the desire to live again after the death of her husband. But precisely how did piano practice function in this way? This article attempts to answer this question by demonstrating that by composing Le Tombeau de Couperin in the jeu perlé style that his friend Marguerite Long preferred, Ravel offered her a way to mourn her husband's death through a kind of highly repetitive, rhythmic, and kinesthetically demanding pianistic performance that was thought to engender emotional transformation. Through close examination of the correspondence, diaries, archives, and published writings of Ravel and musicians in his social circle, this article illuminates the relationship between mourning and musical practice in early twentieth-century France, while rethinking Ravel's Tombeau as written not only for soldiers who died in combat, but also for those who survived them.

$\mathrm{Au}$ début de la Grande Guerre, Maurice Ravel écrivit à Roland-Manuel qu'il commençait à composer Le Tombeau de Couperin. Dans cette même lettre, Ravel lui annonça que Joseph de Marliave, le mari de la pianiste Marguerite Long, avait été tué au champ d'honneur. Le fait que Ravel ait dédié la dernière partie du Tombeau de Couperin au mari de Long et qu'il ait voulu qu'elle donne la première audition de cette œuvre suggère que les nouvelles apportées par cette lettre sont plus liées entre elles qu'il n'y paraît de prime abord. Les musiciens contemporains de Ravel associaient le deuil et la musique, comme en témoigne le fait que Roger-Ducasse ait suggéré à Long en 1915 que jouer du piano pourrait lui donner le désir de continuer à vivre après la mort de son mari. Mais comment s'opère précisément cette fonction consolatrice du piano ? Cet article tente de répondre à cette question en démontrant qu'en composant Le Tombeau de Couperin dans le style du jeu perlé que son amie Marguerite Long préférait, Ravel lui a donné l'occasion de faire son deuil à travers un jeu pianistique répétitif, rythmique et exigeant sur le plan kinesthésique susceptible, pensait-on, d'engendrer une transformation émotionnelle. En examinant la correspondance, les journaux intimes, les archives et les écrits publiés de Ravel et d'autres musiciens au sein de leur cercle social, cet article fait la lumière sur la relation entre le deuil et les pratiques musicales en France au début du vingtième siècle et propose de repenser le Tombeau de Ravel comme une œuvre écrite non seulement pour des soldats morts au combat, mais aussi pour ceux qui leur survécurent. 
INDEX

Mots-clés: La Grande Guerre, Maurice Ravel, Marguerite Long, musique de piano, deuil, musicothérapie, Le Tombeau de Couperin

Keywords: World War I, Maurice Ravel, Marguerite Long, piano music, mourning, music therapy, Le Tombeau de Couperin

\section{AUTHOR}

\section{JILLIAN ROGERS}

Jillian Rogers a reçu son doctorat en musicologie de l'Université de Californie à Los Angeles en 2014. Ses recherches sont centrées sur la relation entre la musique, le deuil et le traumatisme en France dans au XXe siècle. Sa thèse, intitulée « Grieving Through Music in Interwar France :

Maurice Ravel and His Circle, 1914-1934 », examine le rapport entre le deuil et la musique au sein du cercle social de Maurice Ravel. Jill Rogers a présenté ses recherches en France et aux ÉtatsUnis, et elle a été un co-éditeur d'un numéro de revue intitulé Writing About Music pour le Centre des études de la femme à UCLA en 2010. 